Article

\title{
Religious Connotations in Spanish and English Forenames: A Contrastive Study
}

\author{
Inmaculada de Jesús Arboleda-Guirao \\ Departamento Filología Inglesa, University of Murcia, 30100 Murcia, Spain; inma.arboleda@um.es; \\ Tel.: +34-868-889-773
}

Received: 18 October 2020; Accepted: 9 December 2020; Published: 16 December 2020

\begin{abstract}
Names are a subject which concerns us all. Although in recent times the interest in them has grown, until now, most of the research carried out on names in both England and Spain has been devoted to the exploration of surnames and place names. The Bible states that man was created by God on the sixth day with the ability to name. The main purpose of this study was to examine the religious connotations suggested to a group of 425 participants from the metropolitan districts of Murcia (Spain) and Leeds (England) in a list of forenames. A questionnaire with two versions, Spanish and English, was used as the data source in the form of an interview. A mixed methods research was adopted. The findings reveal that, apart from being a stronger influence, the presence of religion was more varied in the metropolitan district of Murcia than in that of Leeds. In addition, only in the former was there a statistically significant relationship between these two socio-demographic and academic factors, age and educational level and religious connotations. Based on the above considerations, we can begin feeling the story behind names.
\end{abstract}

Keywords: religious connotations; forenames; Spanish; English; contrastive study

\section{Introduction}

Names can be a reflection of fashion, family traditions and memories but also religious beliefs (Withycombe [1945] 1977). Bécquer posits that religion can create a society, and this society can create art; thus, religion is a source of art. Catholicism has made use of art to interpret what is in the human soul by means of our senses (Guillén 1979). Giordano (1979) agrees with Bécquer's idea and adds that sweetness is a reflection of divinity, in the same way as love is poetry and religion is a manifestation of endless and pure love.

The Bible states that man was created by God on the sixth day with a significant characteristic: "the ability to name, the ability to speak" (Redmonds 2004, p. 465). As explained in Genesis 2: 18-23, Adam, the first man, named the animals before the creation of Eve. Adam's task was paramount to such an extent that, by giving animals and everything else a name, the whole Creation took on a new and more real existence given that existence was for mankind. This is a second type of creation which complements the first one (Albaigès [1995] 1998). The first man and woman took their name after being expelled from the Paradise because before there was an immortal undifferentiation (Pommier 2013).

For Christians, the forename makes a person into a child of God. The true name of each person is the name given at baptism. Indeed, "to baptise" is regarded as being synonymous with "to name" (Albert 2006). Jesus said, "And I tell you that you are Peter, and on this rock I will build my church" (Mt 13: 16-20). Putting this in different words, the Christian name implies the promise of religious immortality. Baptism implies a second birth, and the godfather and godmother assume the role of a father and a mother (Burguière 1984). Of all the sacraments in the Catholic Church, baptism is the best kept (Besnard and Desplanques 1987). As part of initiation rites there can be different name-giving 
ceremonies that may occur at birth or near birth as in baptism or later in life when new names are adopted (Dunkling 1977).

On another note, for Arabs, and in Al-Bulushi's (2011) words, "the name of a person is a timeless message" (p. 9). The word name is translated into ism in Arabic and it means "sublimity", "highness", "mark", etc. Another illustrative example of the spiritual feeling created by names is depicted in Charlotte Brönte's Jane Eyre, since the religious imagery of the New Jerusalem acts as an instrument to persuade Jane, the main character, to marry St. John, a devoted clergyman (Earnshaw 2012).

Forenames concern us all (Dunkling 1977). Although in recent times the interest in this issue has grown (Valentine et al. 1996; Redmonds 2004), until now, most of the research carried out on names in both England and Spain, which are the focus of this study, has been devoted to the exploration of surnames and place names (Robson 1988; Postles 2002). Hence, names have hardly been examined in terms of factors like religion and even less in current times and from a contrastive perspective between languages. However, a few experts on the field can constitute an exception. Franklin (1986) found no significant link between forename choice and religious and political views, in this case, in fourteenth-century peasants in Thornbury, England. Perl and Wiggins (2004) explored religious connotations for Protestants and Catholics in the USA. Faure ([2002] 2007) included names from deities, such as Zeus, Thor, etc., in his dictionary. Bourin and Martínez-Sopena (2010) studied anthroponomastics in the Middle Ages in Christian France, Spain, England and Hungary. Copeman (2015) examined forenames from a political, social and religious perspective in South Asia.

\section{Religious History of Names in Spain and England}

From the 4th century, there was already a Church tradition in names. The early Church, despite the widespread use of Latin, attempted to suppress classical literature and hide pagan classical history. Nowadays, in the majority of European languages, over half of the conventional forenames come from Christianity. In the twelfth century, the significant role of the Church increased in Western Europe. Great abbeys were founded and the ill-fated Crusades undertaken. In post-revolutionary France or pre-revolutionary Russia, giving names outside the names set by the Church was officially sanctioned. Hanks et al. ([1990] 2006) even claimed that "agnostics and atheists typically choose names for their children that are common among the sect or religion which they may have rejected but in whose midst they live, rather than totally alien or invented names" (p. xi). Redmonds (2004) commented that "Christian names are historically of great interest because they can tell us much about families, communities and culture in past times" (p. vii).

In the medieval mind, women were seen as more devout than men (Clark 1995). As Taillefer de Taillefer de Haya's (2007) study corroborates, during the Renaissance the Church told women to obey their husbands and stay at home, but paradoxically, they gave women access to translations of religious texts which enabled them to take part in the religious controversies taking place at that time. It was the daughter of Edward VI's tutor, Lady Bacon or Anne Cook, who started translating reformist religious works. She contributed to education because there were no reference books in the Renaissance. Differences between genders in terms of names were found in 1377-1383, as the Bible was a source for male names much more than for females. Nonetheless, this situation changed in the sixteenth century as Biblical names were used for both men and women (Redmonds 2004).

In England during the twelfth and thirteenth centuries, Biblical and French Christian names started to displace ancient vernacular names (Baring-Gould 1910). The first source for names in England and other English-speaking countries is the Bible (Darlington 2015). According to Withycombe ([1945] 1977), the Reformation caused the decline in the popularity of non-scriptural saints and their names. Together with the Norman Conquest, it implied a major change in name patterns. Puritans felt that the English Reformation had not gone far enough and that the Church of England was too tolerant with practices they associated with the Catholic Church. The Puritans had a great love of sermons and psalms. They gave names that identified the bearer with a virtue, and these were especially given to 
girls (Boulton 2002). The most popular ones were Charity, Faith, Mercy, Prudence, Obedience, Honesty and Patience (Hanks et al. [1990] 2006).

Most Puritans tended to use biblical names. Rachel, Judith, Ruth, Lydia, Rebecca and Susanna were first used in the mid-sixteenth century (Redmonds 2004). Smith (1985) attributed the onomastic revolution to the fact that settlers in New England, in particular, Hingham, were given Old Testament names (90\% until the 1740s) as a result of the impact of Puritanism. The fact that many names were taken from the Bible increased the number of names coming of Hebrew and Greek origins (Lebel 1946). The Hebrew culture was an unfamiliar culture but their names have become universally known because of Christianity. Abraham was the earliest Old Testament name to be used, followed by Isaac, Nathaniel and Benjamin. The main prophets are Isaiah, Jeremiah, Ezekiel and Daniel (Monter 1979).

Other Protestant Churches such as Calvin's Protestant Reform Church also gave rise to the preference for names from the Old Testament, e.g., Abigail or Adam (Dunkling 1977). Adam was popular but Eve was not as she was said to have brought sin to the world (Hanks et al. [1990] 2006). Jewish people are also fond of biblical names like Sarah, Rebecca, Leah, Rachel, Ruth, Esther, Judith or Miriam and Isaac, Israel, Joel, etc. Aaron, who was the brother of Moses, is a Jewish name which has been increasingly being used in Britain (Dunkling 1977). On many occasions Hebrew female names suggest freshness and charm: Deborah ("bee"), Tamar ("palm tree") or Naomi ("my delight"). There are many more male names than female names in the Bible (3000 versus 170). In some cases, women in the Bible are not known by their names, and their names do not have as many references to God as those of men.

Until the mid-11th century in Spain, religious names came from the Old Testament and saints that the Visigoths venerated (e.g., Félix, Cipriano, etc.). From the 12th century, Catholics adopted Old Testament names but not so intensely as Protestants or Jews did. David, the greatest biblical king of Israel, is one of the most common names among speakers of all creeds. The name was also borne by the patron saint of Wales and two kings in Scotland, which has contributed to its widespread use among Gentiles (Hanks et al. [1990] 2006). In Spain during the last decades of the 12th century, the Gregorian Reform was beginning and the power of the Pope strengthened (Martínez-Sopena 1995a). At the time, evangelical names and those from Roman martyrs and saints from the south of France were used (Martínez-Sopena 1995b). In the 16th century, after the Council of Trent (1545-1563), the Catholic Church promoted names of canonised saints (Monter 1979). In Spain the influence of Roman Catholicism was even more powerful than in Italy. From the 4th century, Christianity started to penetrate the Basque Country, but this land kept its religious singularity for several more centuries. Christianisation in the Basque Country was a slow process which was delayed even until the 10th century. It must be remembered that while Iberia adopted Roman Catholicism, the Basque Country continued to worship animals and the natural elements (the Fire and the Sun, etc.) as deities.

In England there was a deep interest in the saints from the Middle Ages. It was a "fascination and inspiration to people over the centuries" (Redmonds 2004, p. 90), e.g., Margaret in relation to St Margaret of Antioch, although there was a Saint Margaret of Scotland too, or Christopher with the legend of Saint Christopher carrying Christ across the stream. Nicholas was widely used (popularly known as Santa Claus) in France and England in the 10th century. He was one of the most popular saints at the end of the Middle Ages.

New Testament names are very frequent among Christians all over the world, and this shows the pervasiveness of Christianity throughout the past two millennia. In contrast, in the Islamic world and Far East New Testament names are rarely used. The most relevant names in the New Testament are those of the four evangelists: Matthew, Mark, Luke and John (the latter being very popular) as well as the apostles, mainly Peter, James, Andrew, Thomas, Philip and Simon. In Christian belief, the Apostles are very important. There are 12 apostles, which is a symbolic number, as with the tribes of Israel. The Acts of the Apostles and Saint Paul's Epistles also augmented the stock of Christian names, especially those of females such as Chloe or Priscilla. The Scriptures also talk about three archangels: Michael, 
Gabriel and Raphael, within a higher hierarchy of angels, spiritual beings who obey God's commands ${ }^{1}$ (Albaigès [1995] 1998). There are fewer saints' names and fewer significant women in the Gospels, which explains why the number of conventional female names is lower than that of male names or why Mary has become so popular (Mille 1922). Maria Magdalene, the repentant sinner in Luke 7, is one of the characters who appear. In French, the name Madeleine is used, but the fact is that there is no such personal name in the New Testament rather it is a place name. Martha and Elizabeth (the latter was John the Baptist's mother) also appear in the New Testament. Other names derive from the folk tradition: Anne was the Virgin Mary's mother, but there is no evidence to support this in the New Testament. A great number of European names come from the Church fathers (e.g., Ambrose, Jerome, Augustine, etc.), martyrs (Anastasia, Lucy or Sebastian), mystics and visionaries (Francis, Therese, etc.), founders of religious orders (e.g., Benedict, Dominic), etc.

Veneration of local patron saints is very strong both in England and Spain. In France and Italy, there is also veneration of local and national patron saints, which is an important source for forenames. In the 4th century, somebody who led a virtuous life was sanctified even if they had not suffered martyrdom. The communities who had met the person in question could make them a saint without much fuss. Alexander III was the first Pope to restrict the right of canonisation. The person had to be blessed first of all. Hanks et al. ([1990] 2006, p. xv) stated that "in many places in Europe, the name of a local saint is regularly used within a small community". Places and churches were dedicated to these saints. Their protection was invoked. The influence of a Christian name may have been affected by a local church dedication. Each day in the calendar was devoted to the memory of a given saint, normally the date of his/her death (Dager-Nieto n.d.). It would seem that the name in question is resurrected when it is the name day (Tsiropulos 1987). There are names which can be commemorated on several dates since there were several saints with the same name (Dunkling 1977).

By the end of the Middle Ages, around the year 1400, English parents were being affected by local name fashions, e.g., Martin was mainly a Sussex name (Dunkling 1977). In the analysis of poll tax returns of 1377, 1379 and 1381 from Halifax and Leeds, differences could be observed in terms of religious sympathies. In some cases, the cult was more widespread, even to other countries, e.g., Denis, who was the patron saint of Paris, was also a name widely used in England. Biblical names such as Samuel, Jonas, Abraham, Isaac, Daniel or Nathan were amongst the most popular names in rural areas as opposed to more urban areas, in particular, Leeds, in which only Samuel figured amongst the most common names suggesting that Old Testament names had not made a great impact on Leeds, even by 1590. Only those with "a high national profile" (Redmonds 2004, p. 143) like Matthew, Andrew, Mark, Philip and Simon were popular in this city at the time. There were female names most exclusively found in Halifax: Tabitha, Martha, Sarah, Leah and Judith. Likewise, in the 1590s, the Puritan name Gracy was more popular in rural areas (Halifax) than in the city of Leeds. Nonetheless, Elizabeth and Mary could be encountered both in Halifax and Leeds. Local churches dedicated to St. Hilda were also common in North Yorkshire.

For a long time in Spain, names were chosen by the priest considering the saint's day of the child's birth, so rare names like Gelosio or Arquipofotino were selected. The cult of Saint Leocadia is highly localised in Toledo. Jordi is the patron saint in Catalonia and it is very common there (Albaigès [1995] 1998). In the Basque country, saints' names are Txomin, Gorka and Arantzazu (Hanks et al. [1990] 2006). In the municipal district of Murcia, in particular, Algezares, the name Roque is used as a result of the patron saint (Montes del Castillo and Martínez 2011).

Hanks et al. ([1990] 2006, p. xv) explained that "saints can also function as patrons of particular occupations, and we find cases where this, too, influences the choice of a name". For instance, it is not strange to find the daughter of people who love music named after Saint Cecilia. Similarly, Saint Baldomar is the patron of locksmiths in Provence and Iberia. There are iconographic symbols

1 Angel comes from the Greek aggelos: "messenger". 
to represent the saints, for instance, in Spain a shoemaker's tools for Saints Crispín and Cripiniano, a harp or organ for Saint Cecilia or a clover, a symbol of the Trinity in Ireland.

In Christianity for a long time a taboo had existed around holy names (Udo-Solomon 2013). One of the commandments by Moses stated: "You shall not take the name of the Lord your God in vain, for the Lord will not hold him guiltless who takes his name in vain" (Exodus, 20: 7). In 1565, baptised children's parents had to be persuaded not to give children the names of God, Christ, the Angels, etc. (Yonge 1863). The name of God was holy for Jews and it was a blasphemy if you uttered it. The law punished by stoning in those cases. The name of God included four letters: YHVH (in Hebrew the vowels were not represented), and it meant "I am who I am" (Exodus, 3-14), although others like Rabbi Bechal indicated it meant "eternity": "past, present and future". God was known by indirect names: $e l$, iah ("he", "that") (Kirkenir 2014).

Faure ([2002] 2007) clarified that "the name of Maria only starts to be used in Europe from the 9th and 10th centuries onwards as before using the name of Christ's mother was considered to be irreverent, as with the name Jesus" (p. 503, our own translation, emphasis added). María was known by names such as Madre, Virgen, etc., in Spain. Nonetheless, later the taboo against this lack of respect passed (Costarelli 2012) and, in Albaigès's ([1995] 1998, p. 218, our own translation) words, "the name of the Virgin has by a wide margin become the first among those imposed on women in our country, Spain". This author underlines that "the names of members of the Holy Family have always been very familiar and widespread amongst Spanish people" (p. 244, our own translation).

The name Maria has been a focus of scholarly attention throughout history. It is "a name of uncertain and much discussed etymology" (Faure [2002] 2007, p. 502, our own translation). The Latin form Maria was first used in the Bible to refer to Moses' and Aaron's sister (del Rosal 2006). The name was not common at the time. Tibón (2002), and Hanks et al. ([1990] 2006) claim that the consonants in Hebrew were M-R-Y-M (possibly of Egyptian origin), but the name was transcribed with a former /a/ (Mariam) in the Seventy and in the Vulgata as Maria, maybe as a result of thinking that the ending -am was the accusative form. In the New Testament it is a much more frequent name, e.g., Maria of Bethany or Maria Magdalene.

Despite there being several variants of the same name, these variants have a different social history in different countries, e.g., Maria, Mary, Marie, etc. Maria was always more favoured in Christian (especially Catholic) countries. In Spain, the top position in the Early Middle Ages was occupied by this name. After 1950, the name was in decline; however, after 1993 its popularity started to rise again (Albaigès [1995] 1998) thus coming back into favour. In England, Maria came into vogue in 1930. It began to spread in France in the 10th century in its usual form, Marie (Lebel 1946). After the 18th century there was a great devotion to Marie in France. Marion has overcome Marie in France in recent years (Besnard and Desplanques 1987). The Hebrew version of Myriam, with its more traditional spelling Miriam, became popular in Alsace and Lorraine and the south-west France. Miriam could also refer to Maria in Arabic, and it is frequently chosen by parents of Maghrebi origin. In England, Mary declined in popularity after the Reformation due to the associations with Queen Mary. Its popularity seemed to increase later until 1700 though. The name Marie is now replacing Mary in England and Wales. Males have showed a preference for this name (Dunkling 1977).

Albaigès ([1995] 1998, p. 220, our own translation) points out that "Spain is the land of Saint María". Its devotion had already started in the Middle Ages. A chapel, sanctuary or images of María, can be found everywhere in Spain. This gives rise to María being the most frequent name not only on its own but also in combination with other names. To achieve distinction in a way, compounds were used: María del Carmen, María del Pilar, María de las Mercedes, etc. María became just a prefix, the other name achieving a proper entity. The Virgin Mary and her virtues were a guiding light for Catholic women during Franco's dictatorship in Spain. As explained by Tusell (1999), Franco was the head of state from 1936 to 1975. He defended the interests of the Catholic Church. Afterwards, democracy was established with Adolfo Suárez. According to del del Bass (2011), Spanish women could be less 
open-minded in questions of sex and related issues owing to the values and principles which had been inculcated under that dictatorship.

In England devotion is less intense given that Anglicanism does not allow the invocation but just the veneration of the Virgin Mary (Antequera 2010). The dogma of the Immaculate and her ever-present virginity is also repudiated by Anglicans, although nowadays these doctrinal differences between Catholicism and Anglicanism/Protestantism are being renegotiated (Oppenheimer 2005). The Christian use of Mary surpasses that of Fatima, Mohammad's daughter, and Ayesha, one of his wives, among Moslems.

As God is infinite, it has infinite names (Tsiropulos 1987). Likewise, the Virgin has diverse names (Darlington 2015). Hanks et al. ([1990] 2006) note that "in Spain, in particular, a set of female names has grown up associated with different aspects of this cult: names such as Dolores, Mercedes, Concepción, Presentació, and Candelaria" (p. xiv, emphasis added). They refer to mysteries and states of mind of the Virgin during the passion of Christ. Piety dedications include Dolores, Angustias, Purificación, Consolación, Visitación, Socorro, Refugio, Amparo, Soledad, etc. They began to be used at the time the name María was regarded as blasphemous. In some cases, although the original vocabulary was masculine, the names are used in a female form, e.g., Rosario or Pilar. In Italy (Concetta, Assunta) or Ireland (Concepta, Assumpta) similar names can be found but not so frequently.

There are thousands of Marian dedications in Spain (Fernández-Peón 2008). Sometimes they are only used locally but others are used nationally. If a town has a Virgin of Lidón, many girls in the town will be called María de Lidón and this will possibly be reduced to Lidón. In fact, in Murcia there are many women named María de la Fuensanta as a result of the patron saint (Montes del Castillo and Martínez 2011). Nobody has been able to take a census of them because there are nine thousand towns in Spain (Albaigès [1995] 1998). There are even processions in small villages and towns in which the Patrons (Virgins and Saints) parade through the streets surrounded by devout followers. Many studies point out the Marian precedence of female names, for instance, in the Balearic Islands (Bibiloni 2005) with examples such as Montserrat, Meritxell, etc. In Andalusia, the names of Virgins, like Macarena, Rocio, etc., are not abandoned (Albaigès [1995] 1998). The name day of María is the 12th of September, but each Marian advocation has its own name day. Today, the name María has been so frequently repeated in Spain that it is even employed as an equivalent of woman. For instance, mariposa (Maria-posa given that the children wanted the insect to stop and alight) or mariquita (another insect, "a ladybird"). In Cordoba a mariquita is a synonym of servant, a girl who works in a house.

There are many pet forms and derived variants of Maria although they do not have the same intensity (Albaigès [1995] 1998), e.g., Mari, Molly, etc. When the use of this name was forbidden, shortened or pet forms were often employed, especially in England. May had been used for a long time as a shortened form of Mary, although in 1900 it was reinterpreted as the name of the month (Dunkling 1977). Molly (also a pet form of Margaret, as in Molly Brown, who survived the Titanic sinking), Polly and Ria are also hypocorisms of Mary in English. Marion, Mariote, Marionete, etc., began to spread in France in the 10th century (Lebel 1946). Mariette had success in the 1920s and 1930s in France.

One of the factors which has contributed to the strength of Leeds as a city is the presence of diverse religious beliefs: nonconformist, Anglican, Catholic (that is, Christian, the largest religion in this area) as well as Jewish and, nowadays, Hindu, Sikh and Muslim communities, thus resulting in the impressive building of chapels, churches, synagogues, mosques, gurdwaras and mandirs (Hastings 1994). After 1945, as a result of the demographic changes and the increasing number of followers of Eastern religions, there are fewer active Christian and Jewish worshippers in Leeds (Minnis and Mitchell 2007). This is the overall pattern in England although Leeds has been even more diverse and it enjoys a fascinating and consolidated religious history (Ryan 2019). In line with the general trend in Spain, in Murcia the recent religious history points at Catholicism as the most influential belief although in the last years other branches of Christianity, Muslims and Buddhists have started to find their place (Montes del Castillo and Martínez 2011). 
In modern times, we have seen the rise of an individualistic consumer culture. Now, as Redmonds (2004) remarks, we live in an "economic individualism and its increasing egalitarianism" (p. vii). In Western Europe, there has been a decline regarding church membership. Social Issues Research Centre (SIRC) (2007) reported that, whereas in $196474 \%$ of citizens from the UK were practising religious people, only 31\% were by 2005. There are more practising Catholics than Anglicans in Britain (Mazurczak 2014). In Spain, 70\% of the population are Catholics and, of that percentage, the rate of practising Catholics is $15.5 \%$, according to a survey by the Centre for Sociological Research (the Spanish CIS, that is, Centro de Investigaciones Sociológicas) (Ginés 2014). Last but not least, although the gap between the number of practising and non-practising Catholics is still wide, it seems that there has been a mini-renaissance of the Catholic Church in Western Europe in recent years (Mazurczak 2014).

\section{Objectives}

The main purpose of this study was to explore the religious connotations suggested to a selected group of participants from the metropolitan districts of Murcia (Spain) and Leeds (England) in a list of forenames. Several research questions have been formulated and addressed in order to conduct this research:

1. What religious connotations in forenames are found in the metropolitan district of Murcia?

2. What religious connotations in forenames are found in the metropolitan district of Leeds?

These questions will be approached by analysing the following aspects:

- Religious connotations in general terms;

- Religious connotations in terms of the following socio-demographic and academic factors: gender, age, usual place of residence and educational level.

The nature and needs of our research were best met by adopting a complementary or holistic design (i.e., a mixed methods research), which implies including aspects from both the quantitative or neopositivist and the qualitative or interpretative methodological approaches. As Harden and Thomas (2005, p. 257) state, "much research in the 'real world' does not fit into neat categorisations of 'qualitative' and 'quantitative'". A non-experimental descriptive correlational design using a cross-sectional sample survey methodology with one group of subjects was employed.

\section{Key Terms}

For the purposes of the present study the terms which need clarification are defined and operationalised below. The concepts are listed in alphabetical order:

- (Forename) cognate: Given that there is no specific definition of a cognate when referring to names, we offer the following meaning of this term as employed in our study. As defined by Hanks et al. ([1990] 2006), in this research a cognate referred to the same name but as used in another language or country with its corresponding translation, if one existed, e.g., Jéssica ${ }^{2}$ (Spanish) and Jessica (English) or Crispín (Spanish) and Crispin (English).

- Connotation: Connotation is "a feeling or idea that is suggested by a particular word, although it need not be part of the word's meaning, or something suggested by an object or situation" (Walter 2008, p. 295). Generally speaking, connotation is concerned with suggestions.

- $\quad$ Foreign: one of the definitions provided by Walter (2008, p. 560) for the term foreign is "belonging or connected to a country which is not your own".

2 The names analysed in this study are written without italics due to the fact of their constant presence in this paper, although in the Literature Review (Section 2), if cited as examples, as occurs with many other names, they will be in italics. 
Given that the cases of England, Wales, Scotland and Ireland are controversial, further clarification is required. Barrow (2013) explains that England is only one of the three countries making up Great Britain, together with Scotland and Wales. He also comments on the fact that all these countries together with Northern Ireland constitute the United Kingdom, a "country" (Walter 2008, p. 1590). Thus, England would be "a country within a country". The component countries within the United Kingdom (different from England) and other countries outside the United Kingdom will be regarded as foreign. Taking Spain as a reference point, foreign will refer to other countries outside Spain and aspects related to them.

- Middle East(ern)(er): Davison (1960, p. 665) notes, "No one knows where the Middle East is, although many claim to know". According to the Oxford Dictionary (2020), the Middle East is "an extensive area of SW Asia and northern Africa, stretching from the Mediterranean to Pakistan and including the Arabian peninsula", the adjective being Middle Eastern and the derived noun being Middle Easterner. This definition is used in this study and it is in line with that from Davison (1960) in that the Maghreb, which encompasses Morocco, Algeria and Sudan, amongst others, is not excluded. However, in other definitions, such as those found in Walter (2008), only the eastern Mediterranean (including Egypt sometimes) is considered to be part of the Middle East. Habibi (1992) states that Muslims share similar names no matter the exact area.

\section{Methodology}

\subsection{Participants}

One group participated in this study. It comprised 425 males and females. The requirements for a person to be chosen as an informant were as follows:

- $\quad$ Age: over 25.

- Usual place of residence: the metropolitan district of Murcia or Leeds (either the capital city or the surrounding areas, that is, the pedanias ${ }^{3}$ in Murcia or the towns belonging to Leeds).

To ensure as much homogeneity as possible, the sample consisted of a similar percentage of participants in terms of gender (although with a higher percentage of females), age and usual place of residence. The number of respondents aged between 41 and 60 years old was slightly larger. The percentage of subjects with and without higher education was very similar in the metropolitan district of Leeds, but the number of informants without university studies was considerably larger in the metropolitan district of Murcia, the gap between both municipal districts being $21.6 \%$.

\subsection{Instruments}

One questionnaire with two versions, designed by the researcher herself, was used. The reason for a double version was that the target audience was not alike. There were different original languages (i.e., Spanish and English) for questionnaire writing.

The questionnaire, with the two versions, was semi-structured in that it combined closed-ended and opened-ended questions. The structure of the questionnaire followed Serrano's (2008) model and was divided into the following parts: (1) questionnaire introduction (see Appendix A), (2) body of

3 Pedanía is a Spanish term which refers to a small territory that has its own mayor (alcalde pedáneo) but is attached to a municipality and dependent on it (Real Academia Española [2001] 2011). As stated by González-Sicilia (2002, p. 243, emphasis in original), "the municipal district of Murcia is made up of the urban centre of the capital city of the Autonomous Region as well as a series of pedanías". In England, there is not such a clear term. Therefore, a more ambiguous word, town, employed by its own English citizens (Britannica 2020) for the same purpose, is used in the present study. Words and phrases, such as metropolitan district, municipal district, Murcia and pedanias, Murcia/Leeds and its surrounding areas, Leeds and districts, etc. or even Spain/England will be employed interchangeably throughout the text to refer to the whole area. Given that pedanias will be used repeatedly in this paper, when used outside of this footnote, it will not be written in italics. 
socio-demographic and academic questions (see Appendix B) and (3) central question, that is, a relevant question around the research problem, including several items (see Appendices $C$ and D). A more detailed explanation of each part is provided below.

(1) The questionnaire introduction was designed so that the participants understood the objectives of both the research and the results obtained as well as the authorship. The purpose of this introduction was also to motivate the potential respondent by promising anonymity, confidentiality and minimum disruption.

(2) The body of socio-demographic and academic questions (known as factual questions by Dörnyei 2007) aimed to identify the informant. These variables may contribute to "explain" the phenomenon under study and provided the data for the sample description. Each questionnaire consisted of three questions.

(3) The central question, accompanied by instructions for correct completion, elicited responses which contained the essential information to meet the objectives. There was one question which, in turn, contained several sub-questions and ten items (forenames). All of them were opinion and experiential items (Dörnyei 2007). The respondent was required to pinpoint religious connotations, if any, in each of the forenames listed.

\subsection{Procedure}

The study was conducted over a period of one year, from November 2017 to November 2018. During the first semester, data were collected in England while information from Spain was gathered during the second semester.

First of all, the metropolitan districts were chosen, Murcia and Leeds, because, despite their minor population differences ${ }^{4}$, their rural flavour (Calvo 1971) made them appropriate areas for comparative research. Our participants were then selected according to the criteria set out in Section 4.1. A non-probability sampling strategy was used. In particular, there was a quota sample, that is, by freely selecting the subjects, the researcher met the quotas she had already prescribed on the basis of relevant parameters (whose distribution was calculated beforehand) from the perspective of the study (Dörnyei 2007).

Once our respondents had been chosen and after an exhaustive review of the available literature on this or related research areas as well as existing questionnaires, the questionnaire with its two versions was designed (Visauta 1989). As claimed by Connor and Moreno (2005), it should be ensured that what is compared is original and comparable across cultures. The forenames listed were cognates chosen randomly from Faure ([2002] 2007) and Hanks et al. ([1990] 2006), for Spanish and English, respectively.

Following Dörnyei's approach (2007), before launching the project, the research instruments were pilot tested to ensure they worked properly to collect the data needed. The questionnaire was pilot tested with ten individuals with similar characteristics to those of the final sample, with an even ratio of subjects living in England and Spain. The questionnaires were checked and modified on the basis of the recommendations made by the informants in the pilot test.

A personal interview modality was included as this was deemed necessary to foster a climate of confidence and to encourage a deeper level of communication (Rincón 1991). This took about five minutes to fill in. The participation was voluntary from an intentional random selection. The locations were streets, markets and shops. This made willingness to collaborate easier. After explaining what the study consisted of, the interviewer directly interviewed the participants. The semi-structured questionnaire served as a guide for the face-to-face interviews. The interviewer registered the answers in the interview guide.

4 According to FEDER (2019) and Britannica (2020), the metropolitan districts of Murcia and Leeds had populations of 619,500 and 751,485 inhabitants, respectively. 


\section{Data Analysis}

Once the data were collected, they were analysed using the statistical package SPSS 19.0.0 for Windows (SPSS, Inc., an IBM Company [1989] 2010). The information from the variables previously defined according to the scale by which they were measured (nominal and ordinal) was introduced into the data matrices and an exploratory study and an expert consultation were undertaken. The following statistical analyses were then carried out:

- Univariate analysis techniques: frequency and percentage counts were conducted. Graphical techniques, such as bar and pie charts, were used;

- Bivariate analysis techniques: contingency tables were drawn up;

- Association analysis techniques: tests of association were performed in order to assess the level of association between the variables involved, assuming a 95\% confidence interval and a margin of error of $5 \%(\alpha=0.05)$. Pearson's chi square was used to determine whether there was a statistically significant relationship between the variables involved or not.

In those cases where statistically significant associations were found at the alpha levelmentioned above, symmetric (the $\mathrm{V}$ of Cramer) and asymmetric or directional (the uncertainty coefficient) measures of association were calculated. The former made it possible to interpret the degree or magnitude of the association between the two variables (until how much), one not being dependent upon the other (see Table 1). The V of Cramer offered values ranging from 0 to 1 (Bisquerra 1989; Field 2009) which facilitated interpretation. The uncertainty coefficient provided a measure of the degree in which the error was reduced when predicting the dependent variable on the basis of the independent variable. According to Gravetter and Wallnau (2008), it is the researcher who previously defines which predictor and criterion variables are in view of the research objectives, by trying to determine to what extent the dependent variable can be "explained" by the independent variable 5 .

Table 1. Interpretation of correlation coefficients (Bisquerra 1989, p. 189, our own translation).

\begin{tabular}{cc}
\hline Rank & Linear Relationship \\
\hline$=0$ & null \\
$0-0.20$ & very low \\
$0.20-0.40$ & low \\
$0.40-0.60$ & moderate \\
$0.60-0.80$ & strong \\
$0.80-1$ & very strong \\
1 & perfect \\
\hline
\end{tabular}

A qualitative analysis of the quantitative data was carried out. Furthermore, a purely qualitative analysis was undertaken where verbal information was provided by those subjects willing to add spontaneous comments to their answers. The analytical procedure of textual data followed was that proposed by Miles and Huberman (1994). A mixed (deductive-inductive) qualitative approach was employed for the extraction of categories. For the text segmentation the thematic criterium was used. Paraphrases and, mainly, direct quotes were included to support the findings. Likewise, the meanings behind the categories were shown in graphical representations, mainly networks, which assembled and organised the data.

5 Despite this contribution being a descriptive correlational study with no manipulation of variables and, therefore, no dependent or independent variables as such (Rodríguez et al. n.d.), the fact that symmetric and asymmetric measures of association were calculated on the basis of dependent and independent variables, as shown by the SPSS statistical package, led us to employ these two terms, dependent and independent variables, in our study as well. When carrying out asymmetric or directional tests, the variables acting as predictor, grouping or independent variables in this study were gender, age, usual place of residence and educational level. The rest of the variables intervened as criterion or dependent variables. 


\section{Results and Discussion}

The findings in this paper will be discussed by comparing/contrasting religious connotations in the metropolitan districts of Murcia and Leeds (i.e., in the light of the two research questions) and with a focus on two aspects, in this order: (a) religious connotations in general terms; (b) religious connotations in terms of the following socio-demographic and academic factors: gender, age, usual place of residence and educational level.

\subsection{Religious Connotations in General Terms}

Our results reveal that in the metropolitan district of Murcia almost all forenames (except for two) were found to have religious connotations, whereas in the municipal district of Leeds half of the forenames listed, that is, five out of ten, were considered to bear religious connotations (see Figures 1 and 2). From the whole number of religious connotations, almost two-thirds came from Spain (see Figure 3).

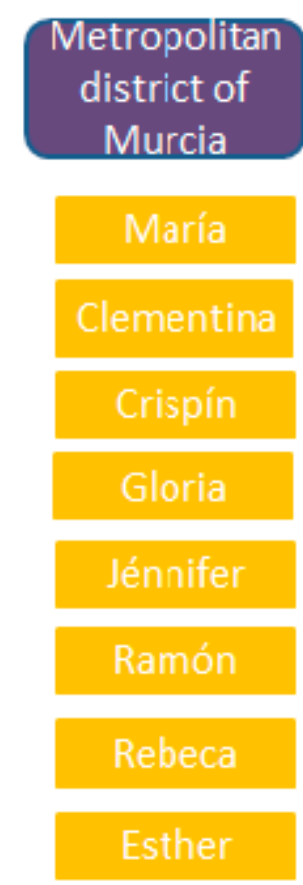

Figure 1. Forenames bearing religious connotations in the metropolitan district of Murcia.

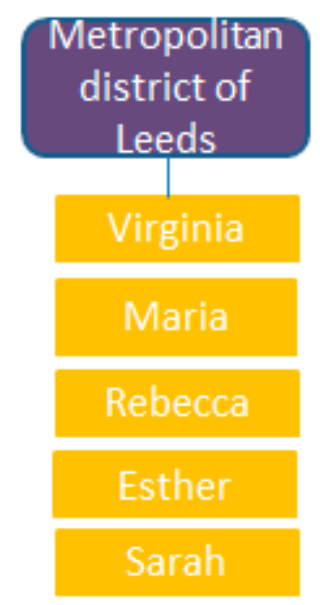

Figure 2. Forenames bearing religious connotations in the metropolitan district of Leeds. 


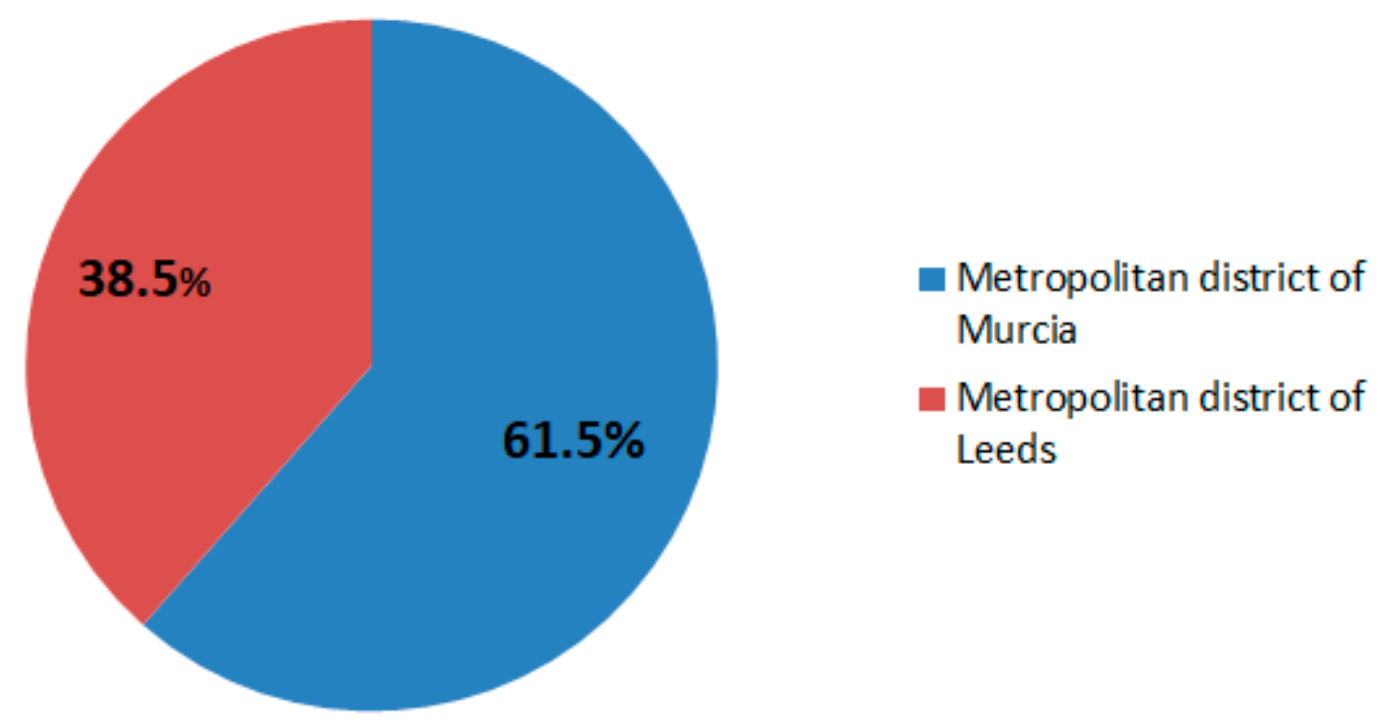

Figure 3. Religious connotations per metropolitan district (percentages).

Rebecca and Esther prompted observations of the type "Rebecca is a biblical name" (e.g., participant 54 ) and "Esther is a name coming from the Bible" (e.g., participant 162) on the part of more than 125 English subjects, that is to say, over $60 \%$. This points to the idea that British people, when religious, have a greater leaning towards the Bible. Old Testament names are frequently used by Jews and Protestants but not so much by Roman Catholics. The primary source for names in England and other English-speaking countries is the Bible (Darlington 2015). During the Reformation, Old Testament names became popular and they were very often used by the Puritans in the 17th century (Faure [2002] 2007). Rebecca, together with other names, such as Rachel, Judith or Ruth, was first used in the mid-sixteenth century (Redmonds 2004).

In the metropolitan district of Murcia these forenames, Rebecca and Esther, triggered comments from only 27 informants, i.e., around $15 \%$, and they are also in relation to the Bible. Actually, participant 87 mentioned: "Estos nombres son del Antiguo Testamento. Fueron mujeres valientes. Dos de mis siete hermanas se llaman así" 6 . This observation came from a follower of the Neocatechumenal Way. The fact that this charism within the Catholic Church offers catechesis to new followers explains why this respondent provides more details about the location of these forenames within the Bible and she is acquainted with the names and even their history. Rebecca was the wife of Isaac ( . . ) and the mother of Esau and Jacob (Genesis, XXIV, 15, as cited by Faure [2002] 2007). Esther was a Jewish orphan who became a Persian Queen (Stoppe 2018). Additionally, we can guess that this subject's family follows The Way in that it is common that its followers have large families with many children thus accepting God's will (Bedoya 2018; Diario 2010).

In the metropolitan district of Leeds, 77 informants (e.g., participant 17), that is, around one-third, identified the forename Virginia as religious and underlined that "Virginia is too chaste a name. I prefer other forms such as Gin or Ginny". The fact that Virginia is the name of a Roman maiden (Hanks et al. [1990] 2006) and its meaning in Latin, virgo, is "virgin, maiden", may contribute to these connotations. In fact, the name of the USA state Virginia had its roots in Elizabeth I of England, the Virgin Queen (Besnard and Desplanques 1987). It would seem that Virginia needs a kind of euphemism which "lexically neutralise[s]" (Casas 1986, pp. 35-36, our own translation) the name in an attempt to avoid using it. However, in this case, it does not sound a nasty or rude word but the opposite, a "too clean" word, according to several people. 
In this respect, Dunkling (1977, p. 119) remarked that "a surge in popularity [of the name Virginia] seems unlikely at the present time because attitudes to 'virginity' have changed so drastically in recent years". In our view, in agreement, for instance, with del Bass (2011) in his experience of flirtation, young British women tend to be open in their sexual life. Maybe the fact that the main religion in England is Anglicanism, which prohibits the invocation of the Virgin Mary-although it is permitted to worship her (Antequera 2010) — may prevent English people from seeing the virtue of Mary's virginity as a point of reference. In addition, the doctrine of the Immaculate Conception and her ever-present virginity is not generally accepted by the Anglican Church, although nowadays Catholicism and Anglicanism are trying to reconcile some doctrinal differences (Oppenheimer 2005). Hence, the name Virginia has probably become embarrassing for these respondents and that is why other forms such as Gin or Ginny are mentioned. It must not be forgotten either that England has been a democratic country longer than Spain, so freedom of thought and action were likely to be more pervasive in English ways of thinking.

Although around 25 subjects in Leeds and its surrounding area, that is, $15 \%$, made reference to the religious connotations in Maria (e.g., "Maria is a religious name"), many more informants in the metropolitan district of Murcia, specifically, over 125 (i.e., more than 60\%) went further, e.g., "María es el nombre de la Virgen y debe emplearse como tal, por respeto, sin abreviar"7 (participant 2). As claimed by Albaigès ([1995] 1998), "the members of the Holy Family have always been very present among Spanish people" (p. 244, our own translation). He also pointed out that "Spain is the land of Saint María" (p. 220, our own translation). A chapel, sanctuary or image of María can be found everywhere in this country. The Virgin Mary and her virtues were a guiding light for Catholic women during Franco's dictatorship in Spain (Tusell 1999). Such is the importance of María that thousands of Marian dedications can be found, either locally or nationally (Fernández-Peón 2008): Dolores, Angustias, Purificación, Consolación, etc. Faure ([2002] 2007) clarified that "the name of Maria only starts to be used in Europe from the 9th and 10th century onwards as before using the name of Christ's mother was considered to be irreverent" (p. 503, our own translation). Notwithstanding this, once it started to be used, it has "amply become the foremost, among those imposed on women in our country" (Albaigès [1995] 1998, p. 218, our own translation), either on its own or in combination with other names. There are also many names coming from María (e.g., Mari in Spanish or Molly in English), although they do not have the same intensity (Albaigès [1995] 1998). That may be the reason why the full name, María, is preferred, as explained by the Spanish respondents, rather than pet names or short versions. What is more, "using a particular label to name a given person denotes something about the nature of the relationship between the speaker and the referred person" (Valentine et al. 1996, p. 16) and the way of addressing someone reflects what the person intends to show (Trubetzkoy [1939] 1973), in this case, respect.

In a related vein, participants 123 and 206, instead of referring to Clementina, the forename listed, mentioned another name which resembled the former in terms of sound, Clementa, and commented on: "Tengo una amiga llamada Clementa por ser el nombre del patrón de su pueblo" 8 . Probably the city where the informants' friend lived was Lorca. In Lorca (Murcia), Saint Clement is the patron along with the Virgin of Orchard (Virgen de las Huertas) (Fernández-Peón 2008; Montes del Castillo and Martínez 2011). Veneration of local patron saints is very strong in Spain. As remarked by Hanks et al. ([1990] 2006, p. xv), "in many places in Europe, the name of a local saint is regularly used within a small community", e.g., the cult of St. Leocadia is highly localised in Toledo. Places and churches were dedicated to these saints and their protection was invoked. There are even processions in small villages and towns in which the Patrons (Virgins and Saints) parade through the streets surrounded by devout followers (Albaigès [1995] 1998).

\footnotetext{
7 "María is the Virgin's forename and it should be employed as such out of respect, without using hypocorisms".

8 "I have a friend called Clementa because it is the name of the patron saint of her town".
} 
Likewise, respondents 150 and 182, who lived in the municipal district of Murcia but whose families came from a town in Alicante stated: "Crispín es nombre del patrón de la ciudad de Elche, en Alicante, concretamente de los zapateros, y la festividad incluye una romería" ${ }^{\prime 9}$. As indicated by Hanks et al. ([1990] 2006, p. xv), "saints can also function as patrons of particular occupations, and we find cases where this, too, influences the choice of a name". There are iconographic symbols to represent the saints, for instance, in Spain it is a shoemaker's tools for St. Crispín and Cripiniano.

When it comes to the name Gloria, participant 186 in Murcia and its surrounding area mentioned, "Gloria bendita" ${ }^{10}$. A similar comment came from 51 informants, i.e., $35 \%$. The fact that this allusion was made in Spain and not in England may be related to Gloria being present in Catholic songs of praise such as Gloria in Excelsis Deo or Gloria Patri et Filio et Spiritu Sancto, in addition to the name making reference to Sábado de Gloria, which in English is known by a different name, Holy Saturday. Another major reason for the allusion of "gloria bendita" in Spain seems to be the dedication to a Virgin, Nuestra Señora de la Gloria, venerated in several Spanish towns (Faure [2002] 2007). Indeed, in Spanish there are many idioms containing Gloria (some of them being synonyms of "heaven" or "paradise") which have their roots in religion: ganarse la gloria ("to go to heaven"), Dios le tenga en su santa gloria ("God rest his soul"), esta piscina es una gloria ("this pool is heavenly"), oler a gloria ("to smell divine"), está que da gloria verla ("she looks wonderful"), sí, gloria ("yes, my love!"), una de las grandes glorias del cine ("one of the great figures of the cinema"), etc. (Diccionario Español-Inglés/English-Spanish [1992] 2000, p. 491).

In addition, in the metropolitan district of Murcia, participant 15 highlighted that he was born on the 31st of August, when the festivity of St. Raymond Nonnatus takes place: "Me gusta Ramón porque nací el día de ese santo"11. Although some scholars, like Lebel (1946), claimed that names do not seem to relate to circumstances of birth, Dunkling (1977) considered that "many parents ( . . ) remember the time of birth in the name" (p. 250). For instance, a person may be called Reyes owing to being born on the Day of the Wise Men or Natividad in the case of being born on the 25th of December and, on many occasions like these, this is related to religion. Actually, for a long time in Spain, names were chosen by the priest according to the saint's day of the child's birth (Albaigès [1995] 1998).

There were 23 Spanish subjects, that is, less than $15 \%$, who showed their radical way of thinking in their comments in allusion to the forename Jénnifer: "Los nombres extranjeros están invadiéndonos; a mí me gustan los nombres normales: los que son cristianos y nos son familiares"12 (participant 95). Foreign names are seen as non-normal. If we consider that the norm is "an accepted standard or way of behaving or doing things that most people agree with" (Walter 2008, p. 966), then, according to this respondent, foreign names are deviations from that standard, that is, Spanish origin. Although many informants were not indeed aware of whether names have Christian roots or not, this subject dared to establish a connection between non-familiarity and non-Christianity. However, participants 95's view is mistaken on the grounds that in the majority of European languages, over half of the conventional forenames come from Christianity (Hanks et al. [1990] 2006) including Spain and England. In particular, as pointed out previously, Spain has a devotion to the Holy Family and their names (Albaigès [1995] 1998). It would have been more accurate on the part of participant 95 to have said Catholic instead of Christian because, although Catholicism is a branch of Christianity, the former is associated more strongly with Spain and not Britain (Hanks et al. [1990] 2006). In any case, the respondent is right in the sense that Jennifer does not have Christian roots. Jennifer is "of Celtic (Arthurian) origin, a Cornish form of the name of King Arthur's unfaithful Guinevere" (Hanks et al. [1990] 2006, p. 141, emphasis added). Moreover, the fact that foreign names are said to be "invading"

9 "Crispín is the name of the patron saint of the city of Elche, in Alicante, in particular, of shoemakers, and the festivity includes a pilgrimage".

10 "Blessed Glory".

1 "I like Ramón since I was born on that saint's day".

"Foreign names are invading us; I like normal names: those which are Christian and are familiar to us". 
us hides a metaphor which portrays a "war" with Spanish people fighting against intruders and a feeling of rejection towards them.

On the other hand, participant 67 stated in regards to the forename Sara: "I write it like that, Sara, and for us, Islamic people, it is a religious name". Almost half of the Saras came from romance language countries, in which the Greek form was adopted (Hanks et al. [1990] 2006). Maybe this is the reason (the spelling Sarah was more frequent in English) and why fewer English informants considered that this name bears religious connotations. In Arabic countries, the standard version was also Sara. In this case, for one participant embracing the Islamic faith, this name did not refer to Abraham's wife and Isaac's mother but to "the wife of the Prophet Ibrahim" (Salahuddin 1999, p. 324). This respondent went further and explained that her name was Tasmia and her father was a Middle Easterner. She was nicknamed Taz. The fact that she has a Quranic name, although having been born and being living in the metropolitan district of Leeds, suggests the strength of Islamic religion (Salahuddin 1999). Some Arab names became popular in the UK in the 1990s (Habibi 1992). Her adaptation to the British culture is shown by means of the nickname adopted (Ullmann 1962). In English, the use of suffixes seems to be very recurrent. One of the suffixes is -s or -z/za in spelling, e.g., Jules from Julia or Fazz from Farrah (de Klerk and Bosch 1997) (see Appendix E for all the comments about religious connotations coming from the metropolitan districts of Murcia and Leeds).

\subsection{Religious Connotations in Terms of Socio-Demographic and Academic Factors}

At this point, the relationship between the participants' socio-demographic as well as academic factors and religious connotations will be analysed. The forenames chosen for this exploration in each metropolitan district are those in which the presence of religious connotations among participants bears a higher percentage.

Firstly, regarding age and with a focus on the names María and Gloria in Murcia and its surrounding area, a statistically significant association was found at a critical value of 0.05 with being a given age as revealed by Pearson's chi-square test $\left(\chi^{2}=11.647 ; d f=2 ; p=0.003\right.$ in the case of María and $\chi^{2}=17.035 ; d f=2 ; p=0.000$ for Gloria). Cramer's V was 0.265 for the former and 0.320 for the latter; thus, the strength of the association was low in both cases as far as Bisquerra's (1989) interpretation is concerned. The value of the uncertainty coefficient showed that when considering the grouping variable in the prediction of the criterion variable, the margin of error would merely be $9 \%$ for María and slightly higher, $11 \%$, for Gloria. For both forenames, it must be highlighted that a similar number of informants (approximately a third) in the three age groups identified religious connotations, but from those respondents who did not observe religious connotations in these names, the vast majority of them (almost three quarters) belonged to the youngest group (see Tables 2 and 3).

This contrasts with the forenames Virginia and Rebecca in Leeds and surrounding areas, in which there was not a statistically significant association between religious overtones and belonging to a given age group, as Pearson's chi-square test points at an associated probability of $0.05\left(\chi^{2}=3.088\right.$; $d f=2 ; p=0.213$ for Virginia and $\chi^{2}=1.455 ; d f=2 ; p=0.483$ for Rebecca). Whereas in Murcia and its surrounding area, the youngest group had an outstanding percentage; in the municipal district of Leeds, there was a balance among all age groups both when attaching and not attaching religious connotations to names (see Tables 4 and 5). It seems that in Spain, most of the participants who did not identify these nuances in the names examined, which may reveal that they do not have knowledge about religion, were young people; however, a difference in terms of age which was not the case in England. This fact may be explained by the data provided by Ginés (2014), who asserted that the rate of practising Catholics, who are indeed knowledgeable about religion, is declining nowadays, although, as can be seen, the rate of connection with religion is still high. 
Table 2. Religious connotations in terms of age for the name María in the metropolitan district of Murcia.

\begin{tabular}{|c|c|c|c|c|c|c|}
\hline \multicolumn{7}{|c|}{ Religious Connotations-María * Age Crosstabulation } \\
\hline & & & \multicolumn{3}{|c|}{ Age } & \multirow{2}{*}{ Total } \\
\hline & & & $25-40$ years old & $41-60$ years old & $61-80+$ years old & \\
\hline \multirow{4}{*}{ Religious connotations-María } & & Count & 16 & 6 & 2 & 24 \\
\hline & No & \% within Religious connotations-María & $66.7 \%$ & $25.0 \%$ & $8.3 \%$ & $100.0 \%$ \\
\hline & & Count & 46 & 45 & 51 & 142 \\
\hline & Yes & \% within Religious connotations-María & $32.4 \%$ & $31.7 \%$ & $35.9 \%$ & $100.0 \%$ \\
\hline \multirow{2}{*}{ Total } & & Count & 62 & 51 & 53 & 166 \\
\hline & & \% within Religious connotations-María & $37.3 \%$ & $30.7 \%$ & $31.9 \%$ & $100.0 \%$ \\
\hline
\end{tabular}

Table 3. Religious connotations in terms of age for the name Gloria in the metropolitan district of Murcia.

\begin{tabular}{|c|c|c|c|c|c|c|}
\hline \multicolumn{7}{|c|}{ Religious Connotations-Gloria * Age Crosstabulation } \\
\hline & & & \multicolumn{3}{|c|}{ Age } & \multirow{2}{*}{ Total } \\
\hline & & & $25-40$ years old & $41-60$ years old & $61-80+$ years old & \\
\hline \multirow{4}{*}{ Religious connotations-Gloria } & \multirow{2}{*}{ No } & Count & 20 & 5 & 3 & 28 \\
\hline & & $\%$ within Religious connotations-Gloria & $71.4 \%$ & $17.9 \%$ & $10.7 \%$ & $100.0 \%$ \\
\hline & \multirow{2}{*}{ Yes } & Count & 42 & 46 & 50 & 138 \\
\hline & & $\%$ within Religious connotations-Gloria & $30.4 \%$ & $33.3 \%$ & $36.2 \%$ & $100.0 \%$ \\
\hline \multirow{2}{*}{ Total } & & Count & 62 & 51 & 53 & 166 \\
\hline & & $\%$ within Religious connotations-Gloria & $37.3 \%$ & $30.7 \%$ & $31.9 \%$ & $100.0 \%$ \\
\hline
\end{tabular}


Table 4. Religious connotations in terms of age for the name Virginia in the metropolitan district of Leeds.

\begin{tabular}{|c|c|c|c|c|c|c|}
\hline \multicolumn{7}{|c|}{ Religious Connotations-Virginia * Age Crosstabulation } \\
\hline & & & \multicolumn{3}{|c|}{ Age } & \multirow{2}{*}{ Total } \\
\hline & & & $25-40$ years old & $41-60$ years old & $61-80+$ years old & \\
\hline \multirow{4}{*}{ Religious connotations-Virginia } & & Count & 11 & 7 & 5 & 23 \\
\hline & No & $\%$ within Religious connotations-Virginia & $47.8 \%$ & $30.4 \%$ & $21.7 \%$ & $100.0 \%$ \\
\hline & & Count & 55 & 67 & 61 & 183 \\
\hline & Yes & $\%$ within Religious connotations-Virginia & $30.1 \%$ & $36.6 \%$ & $33.3 \%$ & $100.0 \%$ \\
\hline \multirow{2}{*}{ Total } & & Count & 66 & 74 & 66 & 206 \\
\hline & & $\%$ within Religious connotations-Virginia & $32.0 \%$ & $35.9 \%$ & $32.0 \%$ & $100.0 \%$ \\
\hline
\end{tabular}

Table 5. Religious connotations in terms of age for the name Rebecca in the metropolitan district of Leeds.

\begin{tabular}{|c|c|c|c|c|c|c|}
\hline \multicolumn{7}{|c|}{ Religious Connotations-Rebecca * Age Crosstabulation } \\
\hline & & & \multicolumn{3}{|c|}{ Age } & \multirow{2}{*}{ Total } \\
\hline & & & $25-40$ years old & $41-60$ years old & $61-80+$ years old & \\
\hline \multirow{4}{*}{ Religious connotations-Rebecca } & \multirow{2}{*}{ No } & Count & 8 & 7 & 4 & 19 \\
\hline & & $\%$ within Religious connotations-Rebecca & $42.1 \%$ & $36.8 \%$ & $21.1 \%$ & $100.0 \%$ \\
\hline & \multirow{2}{*}{ Yes } & Count & 58 & 67 & 62 & 187 \\
\hline & & $\%$ within Religious connotations-Rebecca & $31.0 \%$ & $35.8 \%$ & $33.2 \%$ & $100.0 \%$ \\
\hline \multirow{2}{*}{ Total } & & Count & 66 & 74 & 66 & 206 \\
\hline & & $\%$ within Religious connotations-Rebecca & $32.0 \%$ & $35.9 \%$ & $32.0 \%$ & $100.0 \%$ \\
\hline
\end{tabular}


In the same way that the youngest informants in the municipal district of Murcia stand out as the group who suggested religious connotations less often, those without a university education exceled (in approximately three quarters of cases) as the group who identified these connotations more frequently for both forenames, María and Gloria. This is in line with the previous results concerning age in that the younger the respondent, the more chance he/she had to study at university (see Tables 6 and 7). Hence, the chi-square test indicates that in Spain a statistically significant relationship was found at a critical value of 0.05 between level of education and religious overtones $\left(\chi^{2}=3.907 ; d f=1\right.$; $p=0.048$ for María and $\chi^{2}=5.026 ; d f=1 ; p=0.025$ for Gloria). According to Cramer's V, the degree of intensity in the association was very low, in particular, 0.153 and 0.174 , respectively. The value of the uncertainty coefficient indicated that the error committed when predicting the extent to which these nuances can be "explained" by level of education would only be 3\% for both names. On the other hand, in parallel with the age factor, in the metropolitan district of Leeds, no statistically significant relationship was found between level of education and religious overtones at the aforementioned alpha value for any of the names explored $\left(\chi^{2}=0.218\right.$; $d f=1 ; p=0.641$ for Virginia and $\chi^{2}=1.455$; $d f=2 ; p=0.483$ for Rebecca) (see Tables 8 and 9).

With respect to gender and usual place of residence, there did not exist statistically significant associations between these two factors and religious suggestions at an alpha value of 0.05. Certainly, regarding the former, both for María and Gloria in the municipal district of Murcia $\left(\chi^{2}=2.256 ; d f=1\right.$; $p=0.133$ and $\chi^{2}=0.302 ; d f=1 ; p=0.583$, respectively) and Virginia and Rebecca in the metropolitan district of Leeds $\left(\chi^{2}=464 ; d f=1 ; p=0.496\right.$ and $\left.\chi^{2}=2.256 ; d f=1 ; p=0.133\right)$, there are quite similar reactions on the part of both men and women, with an inclination towards females as is the tendency in the study (see Figures 4-7). It seems that nowadays, the interest in religion does not point to a wide gender disparity, which clashes with the medieval mindset where women were seen as more devout than men (Clark 1995). As for the latter, usual place of residence, the results indicate that there was no statistically significant relationship between this factor and religious overtones at an associated probability of $0.05\left(\chi^{2}=0.413 ; d f=1 ; p=0.520\right.$ for María and $\chi^{2}=0.496 ; d f=1 ; p=0.481$ for Gloria, both in Murcia and its surrounding area, $\chi^{2}=1.335 ; d f=1 ; p=0.248$ for Virginia and $\chi^{2}=1.345 ; d f=1$; $p=0.246$ for Rebecca in Leeds and surrounding towns) either. Indeed, the percentages were very similar between the capital city and the surrounding areas in terms of these connotations. This does not match the religious history of names, since contrasts in terms of names can be found in different areas (urban versus rural, specific cities or towns, etc.) both in England (Dunkling 1977; Redmonds 2004) and Spain (Albaigès [1995] 1998; Montes del Castillo and Martínez 2011) (see Tables 10-13). 
Table 6. Religious connotations in terms of educational level for the name María in the metropolitan district of Murcia.

\begin{tabular}{|c|c|c|c|c|c|}
\hline \multicolumn{6}{|c|}{ Religious Connotations-María * Educational Level Crosstabulation } \\
\hline & & & \multicolumn{2}{|c|}{ Educational Level } & \multirow{2}{*}{ Total } \\
\hline & & & Non-University Education & University Education & \\
\hline \multirow{4}{*}{ Religious connotations-María } & \multirow{2}{*}{ No } & Count & 13 & 11 & 24 \\
\hline & & \% within Religious connotations-María & $54.2 \%$ & $45.8 \%$ & $100.0 \%$ \\
\hline & \multirow{2}{*}{ Yes } & Count & 105 & 37 & 142 \\
\hline & & \% within Religious connotations-María & $73.9 \%$ & $26.1 \%$ & $100.0 \%$ \\
\hline \multirow{2}{*}{ Total } & & Count & 118 & 48 & 166 \\
\hline & & $\%$ within Religious connotations-María & $71.1 \%$ & $28.9 \%$ & $100.0 \%$ \\
\hline
\end{tabular}

Table 7. Religious connotations in terms of educational level for the name Gloria in the metropolitan district of Murcia.

\begin{tabular}{|c|c|c|c|c|c|}
\hline \multicolumn{6}{|c|}{ Religious Connotations-Gloria * Educational Level Crosstabulation } \\
\hline & & & \multicolumn{2}{|c|}{ Educational Level } & \multirow{2}{*}{ Total } \\
\hline & & & Non-University Education & University Education & \\
\hline \multirow{4}{*}{ Religious connotations-Gloria } & & Count & 15 & 13 & 28 \\
\hline & No & $\%$ within Religious connotations-Gloria & $53.6 \%$ & $46.4 \%$ & $100.0 \%$ \\
\hline & & Count & 103 & 35 & 138 \\
\hline & Yes & $\%$ within Religious connotations-Gloria & $74.6 \%$ & $25.4 \%$ & $100.0 \%$ \\
\hline \multirow{2}{*}{ Total } & & Count & 118 & 48 & 166 \\
\hline & & $\%$ within Religious connotations-Gloria & $71.1 \%$ & $28.9 \%$ & $100.0 \%$ \\
\hline
\end{tabular}


Table 8. Religious connotations in terms of educational level for the name Virginia in the metropolitan district of Leeds.

\begin{tabular}{|c|c|c|c|c|c|}
\hline \multicolumn{6}{|c|}{ Religious Connotations-Virginia * Educational Level Crosstabulation } \\
\hline & & & \multicolumn{2}{|c|}{ Educational Level } & \multirow{2}{*}{ Total } \\
\hline & & & Non-University Education & University Education & \\
\hline \multirow{4}{*}{ Religious connotations-Virginia } & \multirow{2}{*}{ No } & Count & 13 & 10 & 23 \\
\hline & & $\%$ within Religious connotations-Virginia & $56.5 \%$ & $43.5 \%$ & $100.0 \%$ \\
\hline & \multirow{2}{*}{ Yes } & Count & 94 & 89 & 183 \\
\hline & & $\%$ within Religious connotations-Virginia & $51.4 \%$ & $48.6 \%$ & $100.0 \%$ \\
\hline \multirow{2}{*}{ Total } & & Count & 107 & 99 & 206 \\
\hline & & $\%$ within Religious connotations-Virginia & $51.9 \%$ & $48.1 \%$ & $100.0 \%$ \\
\hline
\end{tabular}

Table 9. Religious connotations in terms of educational level for the name Rebecca in the metropolitan district of Leeds.

\begin{tabular}{|c|c|c|c|c|c|}
\hline \multicolumn{6}{|c|}{ Religious Connotations-Rebecca * Educational Level Crosstabulation } \\
\hline & & & \multicolumn{2}{|c|}{ Educational Level } & \multirow{2}{*}{ Total } \\
\hline & & & Non-University Education & University Education & \\
\hline \multirow{4}{*}{ Religious connotations-Rebecca } & $\mathrm{No}$ & Count & 7 & 12 & 19 \\
\hline & No & $\%$ within Religious connotations-Rebecca & $36.8 \%$ & $63.2 \%$ & $100.0 \%$ \\
\hline & Yes & Count & 100 & 87 & 187 \\
\hline & Yes & \% within Religious connotations-Rebecca & $53.5 \%$ & $46.5 \%$ & $100.0 \%$ \\
\hline \multirow{2}{*}{ Total } & & Count & 107 & 99 & 206 \\
\hline & & $\%$ within Religious connotations-Rebecca & $51.9 \%$ & $48.1 \%$ & $100.0 \%$ \\
\hline
\end{tabular}




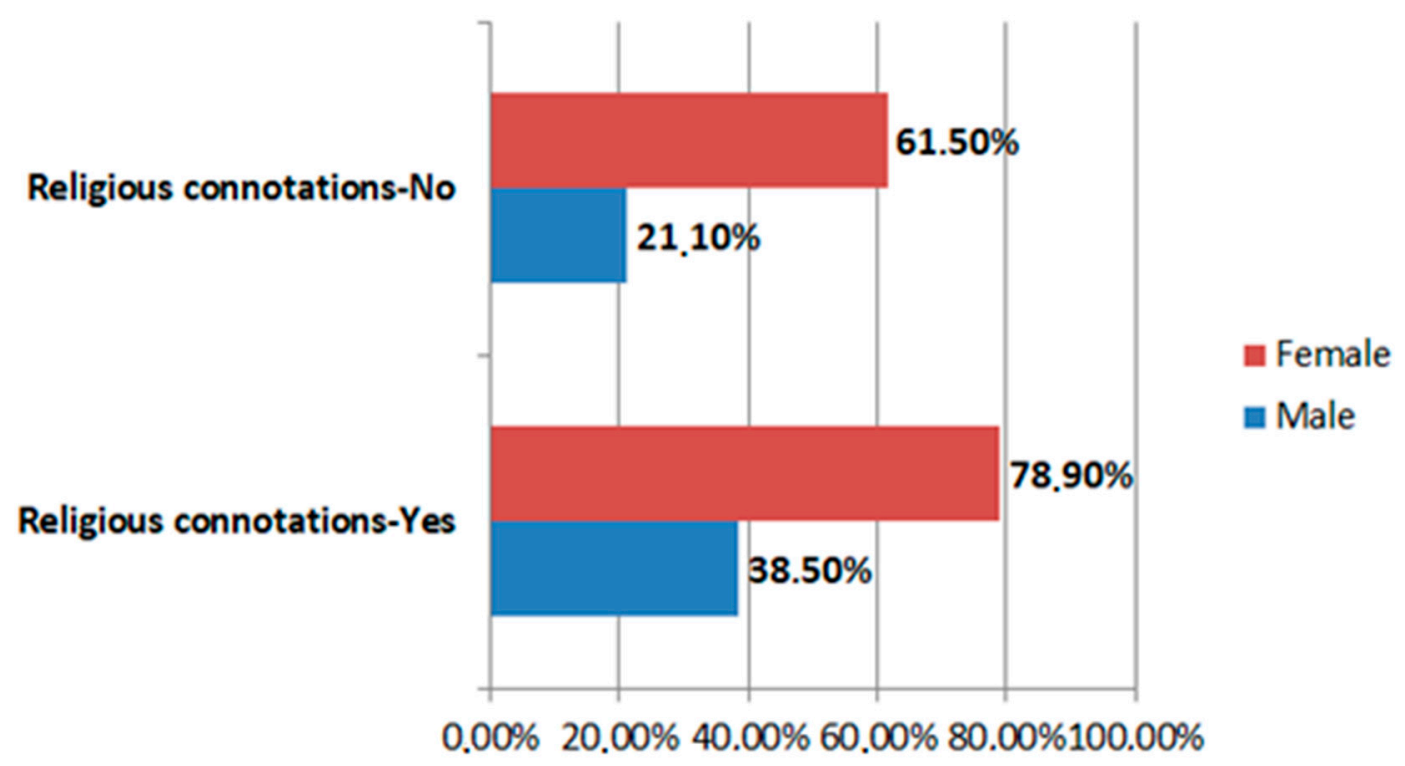

Figure 4. Religious connotations in terms of gender for the name María in the metropolitan district of Murcia.

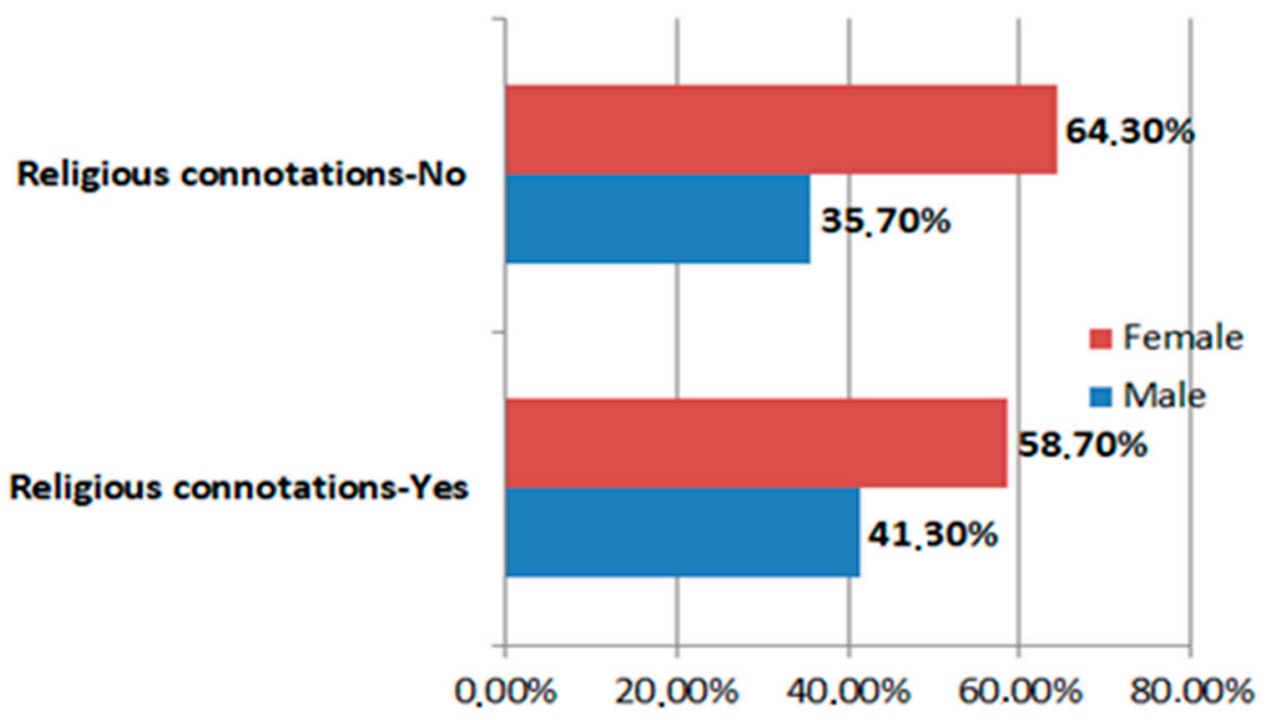

Figure 5. Religious connotations in terms of gender for the name Gloria in the metropolitan district of Murcia. 


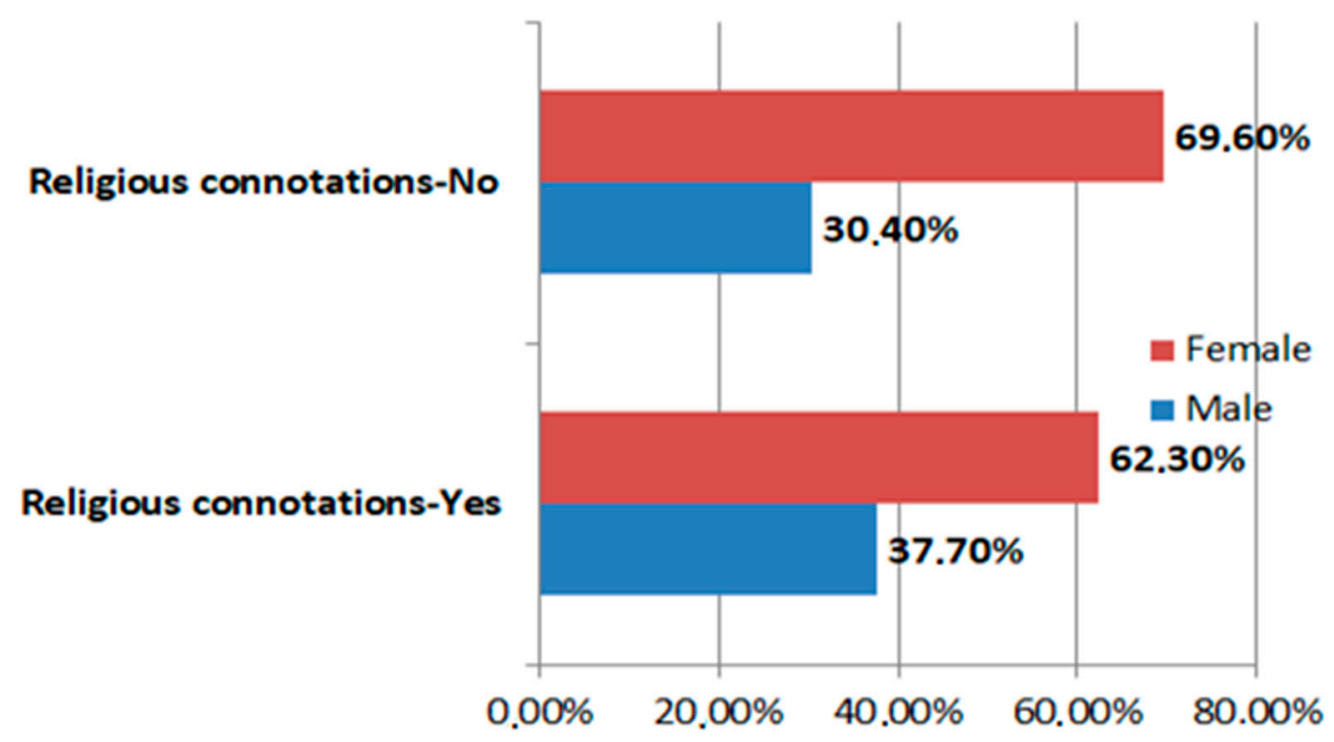

Figure 6. Religious connotations in terms of gender for the name Virginia in the metropolitan district of Leeds.

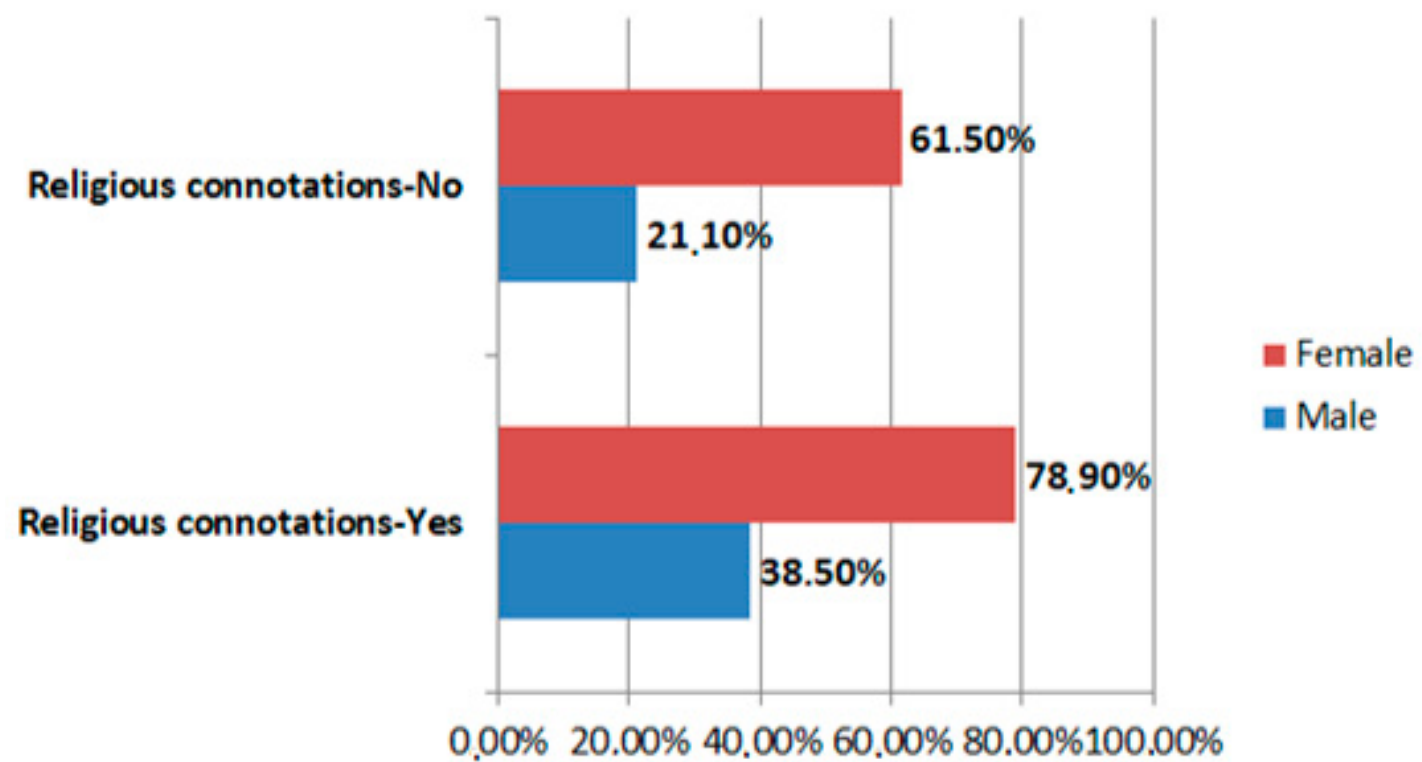

Figure 7. Religious connotations in terms of gender for the name Rebecca in the metropolitan district of Leeds. 
Table 10. Religious connotations in terms of usual place of residence for the name María in the metropolitan district of Murcia.

\begin{tabular}{|c|c|c|c|c|c|}
\hline \multicolumn{6}{|c|}{ Religious Connotations-María * Usual Place of Residence (within the Metropolitan District) Crosstabulation } \\
\hline & & & \multicolumn{2}{|c|}{ Usual Place of Residence (within the Metropolitan District) } & \multirow{2}{*}{ Total } \\
\hline & & & City of Murcia & Pedanía & \\
\hline \multirow{4}{*}{ Religious connotations-María } & \multirow{2}{*}{ No } & Count & 12 & 12 & 24 \\
\hline & & \% within Religious connotations-María & $50.0 \%$ & $50.0 \%$ & $100.0 \%$ \\
\hline & \multirow{2}{*}{ Yes } & Count & 81 & 61 & 142 \\
\hline & & \% within Religious connotations-María & $57.0 \%$ & $43.0 \%$ & $100.0 \%$ \\
\hline \multirow{2}{*}{ Total } & & Count & 93 & 73 & 166 \\
\hline & & $\%$ within Religious connotations-María & $56.0 \%$ & $44.0 \%$ & $100.0 \%$ \\
\hline
\end{tabular}

Table 11. Religious connotations in terms of usual place of residence for the name Gloria in the metropolitan district of Murcia.

\begin{tabular}{|c|c|c|c|c|c|}
\hline \multicolumn{6}{|c|}{ Religious Connotations-Gloria * Usual Place of Residence (within the Metropolitan District) Crosstabulation } \\
\hline & & & \multicolumn{2}{|c|}{ Usual Place of Residence (within the Metropolitan District) } & \multirow{2}{*}{ Total } \\
\hline & & & City of Murcia & Pedanía & \\
\hline \multirow{4}{*}{ Religious connotations-Gloria } & & Count & 14 & 14 & 28 \\
\hline & No & $\%$ within Religious connotations-Gloria & $50.0 \%$ & $50.0 \%$ & $100.0 \%$ \\
\hline & & Count & 79 & 59 & 138 \\
\hline & Yes & $\%$ within Religious connotations-Gloria & $57.2 \%$ & $42.8 \%$ & $100.0 \%$ \\
\hline \multirow{2}{*}{ Total } & & Count & 93 & 73 & 166 \\
\hline & & $\%$ within Religious connotations-Gloria & $56.0 \%$ & $44.0 \%$ & $100.0 \%$ \\
\hline
\end{tabular}


Table 12. Religious connotations in terms of usual place of residence for the name Virginia in the metropolitan district of Murcia.

\begin{tabular}{|c|c|c|c|c|c|}
\hline \multicolumn{6}{|c|}{ Religious Connotations-Virginia * Usual Place of Residence (within the Metropolitan District) Crosstabulation } \\
\hline & & & \multicolumn{2}{|c|}{ Usual Place of Residence (within the Metropolitan District) } & \multirow{2}{*}{ Total } \\
\hline & & & City of Leeds & Town Belonging to Leeds & \\
\hline \multirow{4}{*}{ Religious connotations-Virginia } & \multirow{2}{*}{ No } & Count & 9 & 14 & 23 \\
\hline & & \% within Religious connotations-Virginia & $39.1 \%$ & $60.9 \%$ & $100.0 \%$ \\
\hline & \multirow{2}{*}{ Yes } & Count & 95 & 88 & 183 \\
\hline & & $\%$ within Religious connotations-Virginia & $51.9 \%$ & $48.1 \%$ & $100.0 \%$ \\
\hline \multirow{2}{*}{ Total } & & Count & 104 & 102 & 206 \\
\hline & & $\%$ within Religious connotations_-Virginia & $50.5 \%$ & $49.5 \%$ & $100.0 \%$ \\
\hline
\end{tabular}

Table 13. Religious connotations in terms of usual place of residence for the name Rebecca in the metropolitan district of Murcia.

\begin{tabular}{|c|c|c|c|c|c|}
\hline \multicolumn{6}{|c|}{ Religious Connotations-Rebecca * Usual Place of Residence (within the Metropolitan District) Crosstabulation } \\
\hline & & & \multicolumn{2}{|c|}{ Usual Place of Residence (within the Metropolitan District) } & \multirow{2}{*}{ Total } \\
\hline & & & City of Leeds & Town belonging to Leeds & \\
\hline \multirow{4}{*}{ Religious connotations-Rebecca } & & Count & 12 & 7 & 19 \\
\hline & No & $\%$ within Religious connotations—Rebecca & $63.2 \%$ & $36.8 \%$ & $100.0 \%$ \\
\hline & & Count & 92 & 95 & 187 \\
\hline & Yes & $\%$ within Religious connotations—-Rebecca & $49.2 \%$ & $50.8 \%$ & $100.0 \%$ \\
\hline \multirow{2}{*}{ Total } & & Count & 104 & 102 & 206 \\
\hline & & \% within Religious connotations-Rebecca & $50.5 \%$ & $49.5 \%$ & $100.0 \%$ \\
\hline
\end{tabular}




\section{Conclusions}

In this study, we explored the religious connotations suggested to a selected group of participants from the metropolitan districts of Murcia (Spain) and Leeds (England) in a list of forenames.

With regard to religious overtones in general terms, we can conclude that, apart from being a stronger influence (with a higher rate of forenames carrying these connotations), the presence of religion is more varied in terms of religious figures, activities and events in the metropolitan district of Murcia than in that of Leeds (see Appendix F for a summary of the main points), in line with the general trend in Spain and England. This is somehow connected to Perl and Wiggins's (2004) results in the USA as Catholics (and Spain has a preponderance of Catholics, a 70\% presence, according to Ginés 2014), especially practising Catholics, perceive more religious connotations in forenames. In our study, whereas the only comments in the metropolitan district of Leeds were in reference to the Bible, which reinforces the idea of it being the first source for names in England and other English-speaking countries (Darlington 2015); in the municipal district of Murcia local saints, the Virgin, pilgrimages or processions (Montes del Castillo and Martínez 2011) are highlighted. Although veneration of local patron saints is also strong in England (Hanks et al. [1990] 2006), the custom of pilgrimages seems to be better established in Spain not only with saints but also with the Virgin, referred to without using pet forms in order not to lose intensity and respect: "Spain is the land of Saint María" (Albaigès [1995] 1998, p. 220) while devotion to her is less intense in Anglicanism (Antequera 2010). In fact, sexual connotations seem to be more widely present in the metropolitan district of Leeds, maybe by virtue of the more open attitude towards sex on the part of English women (del Bass 2011). It must not be forgotten either that the Immaculate Conception and her ever-present virginity is not generally accepted by the Anglican Church (Antequera 2010), and England has been a democratic country longer than Spain, so freedom of thought and action were likely to be more pervasive in English ways of thinking, in general terms. The Virgin Mary and her virtues were a guiding light for Catholic women during Franco's dictatorship in Spain (Tusell 1999). Additionally, religion idioms and the presence of religion in everyday life (e.g., naming a person after the saint of that day) were remarked in the metropolitan district of Murcia. On the basis of the foregoing, it is not surprising to find more radical comments on the part of Spanish informants even showing rejection towards non-Catholic names. This research also offers very broad brushstrokes about the Islamic faith which reveal the strength of their religion (by using names coming from Islam) even when living in a foreign country. It must be taken into account that other faiths are "living together" with Christianity both in Leeds and Murcia (Minnis and Mitchell 2007; Montes del Castillo and Martínez 2011).

With respect to religious connotations in terms of socio-demographic and academic factors, the only municipal district which showed a statistically significant association was Murcia and pedanías and the factors concerned were age and educational level. Thus, Pearson's chi-square test pointed at statistically significant differences at an associated probability of 0.05 amongst age groups and type of studies (university versus non-university) in the metropolitan district of Murcia. Nonetheless, in Leeds and its surrounding areas these factors did not have a bearing on religious overtones for names. In fact, none of the factors (i.e., age, educational level, gender and usual place of residence) were linked to these suggestions in England, the latter two neither in Spain.

Based on the above considerations, we come to know the context in which we live and how this context and its history affect our language, in particular, forenames. Our names are a sense of our identity. They define who we and our ancestors are and describe us, in this case, spiritually. By paying attention to these religious connotations, we can discover the richness of forenames: they have a story behind them. This is summarised in the following revealing quotation: "Be still. Remember my name. It is the label that is attached to me. It is the one thread that is sewn through this entire story. Your story or my story -it is only the stitching that changes. The want is the thing that drives us. Trust me: I have a story to tell" (Payment 2015, p. 6).

The results obtained in this paper have provided us with some significant findings, but there are limitations which need to be highlighted. Using a more substantial number of name exemplars would 
be recommended in order to further substantiate and validate the conclusions of this study. Given that there was only one Muslim among our respondents, we could not examine the Islamic religion in depth. It would be recommended to increase the number of followers of Islam within the group of informants. It could also be of interest for future studies to approach forenames from the standpoint of factors other than religion such as social class, meaning or fashion.

Funding: We are indebted to a research scholarship from the Regional Agency for Science and Technology of the Region of Murcia Fundación Séneca which has allowed us to explore this challenging topic.

Acknowledgments: Sincere thanks go to Rafael Monroy, my colleague at the University of Murcia and Ph.D. thesis supervisor, for fuelling my interest in the subject. I would also like to express my deep sense of gratitude to my colleague, María del Mar Vilar, for her insightful suggestions and her words of encouragement.

Conflicts of Interest: The author declares no conflict of interest. The funders had no role in the design of the study; in the collection, analyses, or interpretation of data; in the writing of the manuscript, or in the decision to publish the results.

\section{Appendix A}

\section{Questionnaire (Spanish)}

Estimado/a Sr/a:

Mi nombre es Inmaculada Arboleda. Soy profesora de la Universidad de Murcia. Estamos realizando una investigación sobre las reacciones de las personas ante nombres, en concreto, sus connotaciones religiosas. Su colaboración es muy importante para que llevemos a cabo el estudio. Aunque el cuestionario está por escrito, se hará como entrevista. No hay respuestas correctas ya que hay preguntas sobre sus opiniones. Puede añadir todos los comentarios que quiera contestando dichas preguntas. Responderemos a todas las dudas que puedan surgir durante la entrevista. No llevará más de 5 minutos cumplimentarla y esperamos que le resulte amena pues se trata de un tema muy popular en nuestra vida diaria. El anonimato y confidencialidad están garantizados. Le reiteramos nuestro agradecimiento más sincero por su colaboración. Facilito mi dirección de correo a continuación en caso de que esté interesado en obtener más datos acerca de la investigación o conocer los resultados del estudio.

Inmaculada Arboleda Guirao

E-mail: inma.arboleda@um.es

\section{Questionnaire (English) \\ Dear Sir/Madam,}

My name is Inmaculada Arboleda. I work as a lecturer at the University of Murcia. We are carrying out a research project on the reactions of people to forenames, in particular, their religious connotations. Your collaboration is very important for us to be able to conduct the study. Although the questionnaire is written, it will be done as an interview. There are no correct answers, as these are questions about your opinions. You can add all the comments you like answering those questions. We will answer any doubts that may arise during the interview. It will take no longer than $5 \mathrm{~min}$ to complete and we hope you will find it enjoyable as this is a very popular topic in everyday life. Anonymity and confidentiality will be guaranteed. We reiterate our sincere thanks to you for your collaboration. Below, my email account is included in case you are interested in receiving further information about this research or in knowing the results of the study.

Inmaculada Arboleda Guirao

E-mail: inma.arboleda@um.es 
Appendix B

SPANISH

- Marque sus datos personales:

Sexo: V $\mathrm{V} \quad \mathrm{M} \square$

Edad:

25-40

41-60

61-80+

Nivel educativo:

Universitario

No universitario

\section{ENGLISH}

- $\quad$ Tick your personal data:

Gender: $\mathrm{M} \square \quad \mathrm{F} \square$

Age:

25-40

41-60

61-80+

Level of education:

University

Non-university

\section{Appendix C}

\section{SPANISH}

1. Indique si considera que alguno/s de estos nombres tiene connotaciones religiosas $\mathbf{y}$, de ser así, explique por qué. Puede añadir todos los comentarios que crea oportunos.

Rebeca

CONNOTACIÓN RELIGIOSA: SÍ/NO

CUANDO LA RESPUESTA ES “SI'”, EXPLIQUE POR QUÉ:

ENGLISH

1. Please indicate if you consider that any of these forenames bear religious connotations and, if so, explain why. You can add any comments you consider.

Rebecca

RELIGIOUS CONNOTATION: YES/NO

WHEN THE ANSWER IS "YES", EXPLAIN WHY:

\section{Appendix D}

1. Rebeca/Rebecca

2. Ramón/Ramone

3. Jénnifer/Jennifer

4. Gloria/Gloria

5. Crispín/Crispin 
6. Clementina/Clementine

7. Esther/Esther

8. Sara/Sarah

9. Virginia/Virginia

10. María/Maria

\section{Appendix E}

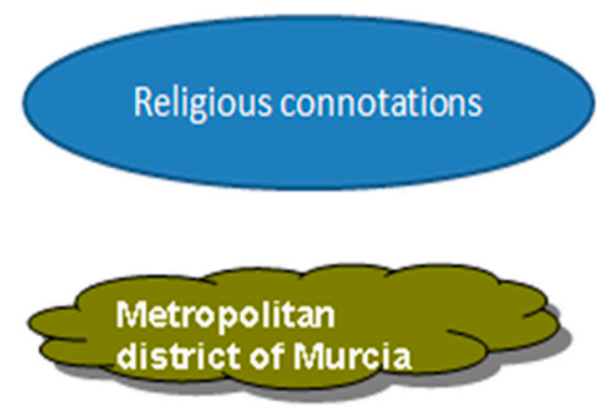

- (Rebeca and Esther): “These names come from the Old Testament. Two of my seven sisters are named like that"

- (María): "María is the Virgin's forename and it should be employed as such out of respect, without using hypocorisms"

- (Clementa): "I have a friend called Clementa because it is the name of the patron saint of her town"

- (Crispín): "Crispín is the name of the patron saint of the city of Elche, in Alicante, in particular, of shoemakers, and the festivity includes a pilgrimage"

- (Gloria): "Blessed Glory"

- (Ramón): "I like Ramón since I was born on that saint's day"

- (Jennifer): "Foreign names are invading us; I like normal names: those which are Christian and are familiar to us"

\section{Metropolitan}

\section{district of Leeds}

- (Rebecca): "Rebecca is a biblical name"

- (Esther): "Esther is a name coming from the Bible"

- (Virginia): "Virginia is too chaste a name. I prefer other forms such as Gin or Ginny"

- (Maria): "Maria is a religious name"

- (Sara): I write it like, Sara, and for us, Islamic people, it is a religious name" 


\section{Appendix F}

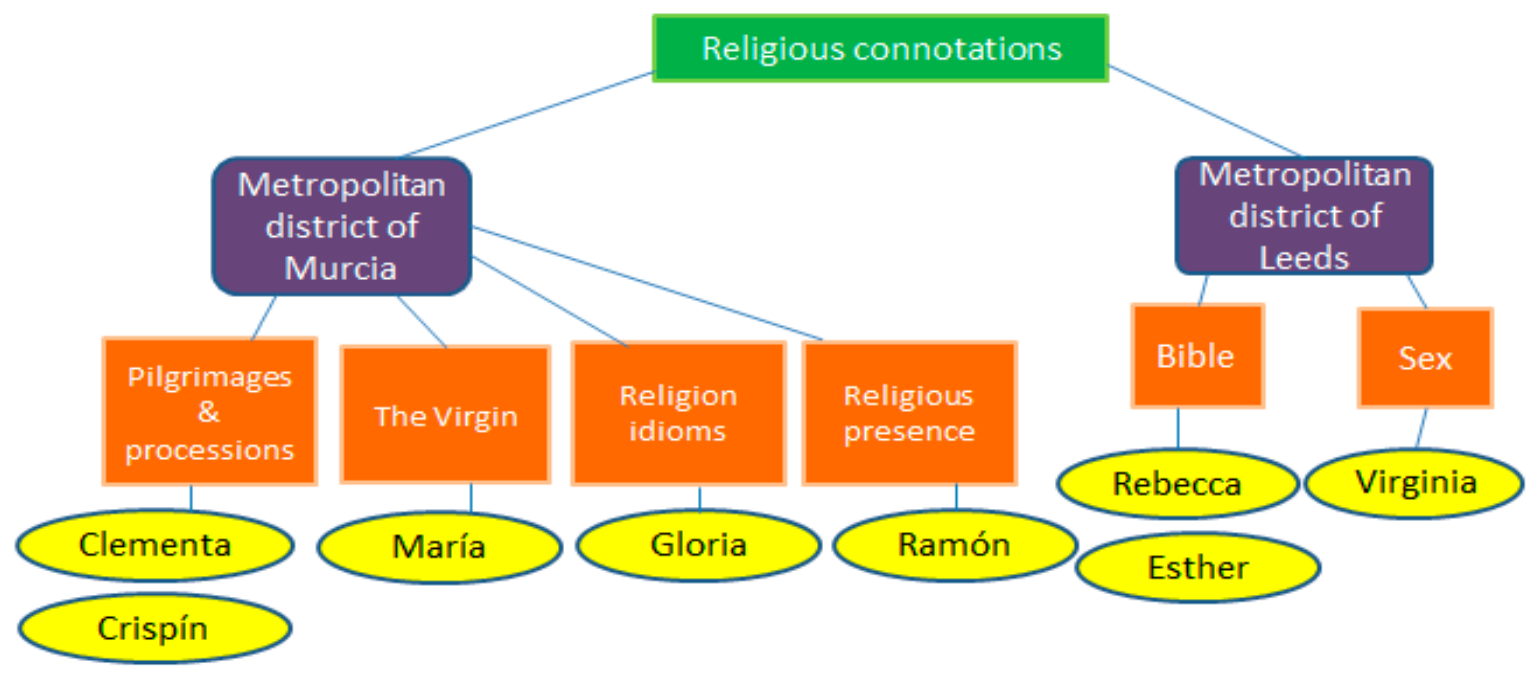

\section{References}

Albaigès, Josep María. 1998. Enciclopedia de los nombres propios. El origen y significado de todos los nombres: Sus diminutivos, sus derivados, sus anécdotas [Encyclopaedia of proper names. The origin and meaning of all names: Diminutives, derivatives and anecdotes]. Barcelona: Planeta. First published 1995.

Albert, Jean Pierre. 2006. La transmission des prénoms. Quelques enjeux religieux d'une dérégulation [The transmission of forenames. Some religious issues of deregulation]. In Le nom dans les sociétés occidentals contemporaines. Edited by Agnès Fine and Françoise Romaine Ouellette. Toulouse: Presses Universitaires du Mirail.

Al-Bulushi, Samar. 2011. Names and Naming Systems in Oman. Paper presented at the 24th International Congress of Onomastic Sciences, Barcelona, Spain, September 5-9.

Antequera, Luis. 2010. De católicos y anglicanos y lo que les diferencia [Catholics and Anglicans and the differences between them]. Religión en Libertad. Available online: http://www.religionenlibertad.com/decatolicos-y-anglicanos-y-lo-que-les-diferencia-7226.htm (accessed on 23 August 2020).

Baring-Gould, Sabine. 1910. Family Names and Their Story. London: Seeley \& Co. Limited.

Barrow, Mandy. 2013. What Is Great Britain. Project Britain. Woodlands Junior. Available online: http: //projectbritain.com/ (accessed on 12 September 2019).

Bedoya, Juan G. 2018. Quiénes son los 'kikos', el movimiento católico que saca músculo ante el Papa. El País. Available online: https:/elpais.com/politica/2018/05/09/sepa_usted/1525885861_324010.html (accessed on 26 February 2020).

Besnard, Philippe, and Guy Desplanques. 1987. Un prénom pour toujours. La cote des prénoms hier, aujourd'hui et demain [A forename forever. The popularity rating of forenames yesterday, today and tomorrow]. Revue française de Sociologie 28: 708-11.

Bibiloni, Gabriel. 2005. La normalització de l'antropotoponímia [The normalisation of anthroponymy]. In Jornades d'antroponímia i toponímia (2003-2004). Edited by Herminia Planisi. Palm of Majorca: Universitat de les Illes Balears, pp. 213-20.

Bisquerra, Rafael. 1989. Introducción Conceptual al Análisis Multivariable. Un Enfoque Informático con los Paquetes SPSS-X, BMDP LISREL y SPAD [Conceptual introduction to the multivariate analysis. A computer approach with the software SPSS-X, BMDP LISREL and SPAD]. Barcelona: PPU.

Boulton, Jeremy. 2002. The naming of children in Early Modern London. In Naming, Society and Regional Identity. Edited by D. Postles. Oxford: Leopard's Head Press, pp. 147-67.

Bourin, Monique, and Pascual Martínez-Sopena. 2010. Anthroponymie et Migrations dans la Chrétienté Médievale [Anthroponymy and migrations in medieval Christianity]. Madrid: Casa de Velázquez. 
Britannica. 2020. Leeds, England, United Kingdom. Available online: https://www.britannica.com/place/LeedsEngland (accessed on 15 March 2020).

Burguière, Andrè. 1984. Prénoms et parenté [Forenames and kinship]. In Le prénom: Mode et histoire: Entretiens de Malher 1980. Edited by Jacques Dupâquier, Alain Bideau and Marie Elizabeth Ducreux. Paris: École des Hautes Études en Sciences Sociales, pp. 247-53.

Calvo, Francisco. 1971. Aspectos de la evolución de la propiedad territorial en la huerta de Murcia [Aspects of the Evolution of Territorial Property in the Murcian Orchard Area]. Papeles de Geografía. Available online: https://revistas.um.es/geografia/article/view/41361 (accessed on 17 April 2019).

Casas, Miguel. 1986. La Interdicción lingüística. Mecanismos del eufemismo y disfemismo [Linguistic interdiction. Mechanisms of euphemism and dysphemism]. Cádiz: Servicio de Publicaciones Universidad de Cádiz.

Clark, Cecily. 1995. Socio-economic status and individual identity: Essential factors in the analysis of Middle English personal naming. In Words, Names and History: Selected Writings of Cecily Clark. Edited by Peter Jackson. Cambridge: Brewer, pp. 100-13.

Connor, Ulla, and AnaI. Moreno. 2005. Tertium comparationis: A vital component in contrastive rhetoric research. In Directions in Applied Linguistics: Essays in Honour of Robert B. Kaplan. Edited by Paul Bruthiaux, Dwight Atkinson, William Eggington, William Grabe and Vaidehi Ramanathan. Clevedon: Multilingual Matters, pp. 153-64.

Copeman, Jacob. 2015. Secularism's names: Commitment to confusion and the pedagogy of the name. South Asia Multidisplinary Academic Journal 12: 1-26. [CrossRef]

Costarelli, Rafael Ernesto. 2012. Antroponimia en la antigua lírica popular hispánica (siglos xv a xvii). Notas para un cancionero basado en los nombres [Anthroponymy Based on the Old Hispanic Popular lyrical poetry (15th to 17th Centuries). Notes for an Anthology Based on Names]. Lemir: Revista De Literatura Española Medieval Y Del Renacimiento 16: 161-270. Available online: http://parnaseo.uv.es/Lemir/Revista/Revista16/03_ Costarelli_Rafael.pdf (accessed on 12 January 2019).

Dager-Nieto, Juan. n.d. Historia y significado de los nombres de personas, amén de otras cosillas [History and Meaning of People's Names, in Addition to Other Things]. Café Berlín. Available online: http: //www.delagracia.de/dager.pdf (accessed on 21 November 2019).

Darlington, Roger. 2015. British Names: First Names. What's in a Name? Available online: http://www. rogerdarlington.me.uk/useofnames.html\#FIN (accessed on 23 October 2019).

Davison, RodericH. 1960. Where is the Middle East? Foreign Affairs 38: 665-75. [CrossRef]

de Klerk, V., and B. Bosch. 1997. The sound patterns of English nicknames. Language Sciences 19: 289-301. [CrossRef] del Bass, David. 2011. ¿Es tan Complicado Ligar en España? [Is It so Difficult to Pick up in Spain?]. Seducción y Superación. Available online: http://seduccionysuperacion.com/2011/04/08/\%C2\%BFes-tan-complicado-ligaren-espana/ (accessed on 14 July 2019).

del Rosal, Francisco. 2006. El origen de los nombres: Alfabeto segundo de la obra "Origen y etymologia, de todos los vocablos originales de la lengua castellana" [The origin of names: Second alphabet of the work "Origin and etymology of every original word in the Spanish language"]. Cordoba: Plurabelle \& Berenice.

Diario, Sur. 2010. Camino Neocatecumenal ('kikos'), familias que tienen hasta trece hijos. Diario Sur. Available online: https://www.diariosur.es/v/20101219/malaga/camino-neocatecumenal-kikos-familias-20101219.html (accessed on 19 February 2020).

Diccionario Español-Inglés/English-Spanish. 2000. New York: HarperCollins Publishers. First published 1992.

Dörnyei, Zoltan. 2007. Research Methods in Applied Linguistics. Oxford: Oxford University Press.

Dunkling, Leslie Alan. 1977. First Names First. London: Coronet Books/Hodder and Stoughton.

Earnshaw, Steven. 2012. 'Give me my name': Naming and identity in and around Jane Eyre. Brontë Studies 37: 173-88. [CrossRef]

Faure, Roberto. 2007. Diccionario de Nombres Propios [Dictionary of proper names]. Madrid: Espasa Calpe. First published 2002.

Fondo Europeo de Desarrollo Regional (FEDER). 2019. Estrategia de Desarrollo Urbano Sostenible Integrado. Available online: https://www.estrategiamurcia.es/upload/2019/01/EDUSI_MURCIA.pdf (accessed on 19 March 2019).

Fernández-Peón, José Manuel. 2008. Religión y milicia. El apóstol Santiago: Su huella en la historia de España [Religion and militia. The apostle James: His footprint in the Spanish history]. Murcia: Universidad Católica San Antonio.

Field, Andy. 2009. Discovering Statistics Using SPSS (Introducing Statistical Method). London: SAGE. 
Franklin, Peter. 1986. Normans, Saints and Politics: Forename Choice among Fourteenth-Century Gloucestershire Peasants. Available online: http://www.localpopulationstudies.org.uk/PDF/LPS36/LPS36_1986_19-26.pdf (accessed on 12 January 2019).

Ginés, Pablo J. 2014. En este año con Francisco, creció 3 puntos el porcentaje de católicos practicantes en España [This Year, with Frances, the Percentage of Practising Catholics in Spain Increased 3 Points]. Religión en Libertad. Available online: http://www.religionenlibertad.com/en-este-ano-con-francisco-crecio-3-puntos-elporcentaje-de-34330.htm (accessed on 13 May 2020).

Giordano, Jaime. 1979. Darío a la luz del simbolismo [Darío in the light of symbolism]. In El simbolismo. Edited by J.O. Jiménez. Madrid: Taurus Ediciones, pp. 126-59.

González-Sicilia, Manuel. 2002. Los medios audiovisuales y el centro de recursos de la comunidad autónoma de Murcia en los centros de primaria de Murcia. Presencia y usos [Audiovisual media and the resource centre in the autonomous community of Murcia in primary centres in Murcia. Presence and uses] (Unpublished doctoral dissertation). Murcia: University of Murcia.

Gravetter, Frederick J., and Larry B. Wallnau. 2008. Statistics for the Behavioral Sciences. Belmont: Wadsworth.

Guillén, Jorge. 1979. La poética de Bécquer [Bécquer's poetics]. In El Simbolismo. Edited by José Olivio Jiménez. Madrid: Taurus Ediciones, pp. 95-107.

Habibi, Nader. 1992. Popularity of Islamic and Persian names in Iran before and after the Islamic Revolution. International Journal of Middle East Studies 24: 253-60. [CrossRef]

Hanks, Patrick, Kate Hardcastle, and Flavia Hodges. 2006. Oxford Dictionary of First Names. Oxford: Oxford University Press. First published 1990.

Harden, Angela, and James Thomas. 2005. Methodological issues in combining diverse study types in systematic reviews. International Journal of Social Research Methodology 8: 257-71. [CrossRef]

Hastings, Adrian. 1994. The role of Leeds within English religious history. In Religion in Leeds. Edited by Alistair Mason. Stroud: Alan Sutton.

Kirkenir, Joseph L. 2014. I Am Who I Am: The Book of Exodus and African American Individuality. Student Publications, Paper 212. Honors thesis, Gettysburg College, Gettysburg, PA, USA. Available online: https://cupola.gettysburg.edu/cgi/viewcontent.cgi?article=1275\&context=student_scholarship (accessed on 14 June 2019).

Lebel, Paul. 1946. Les noms de Personnes en France [People's names in France]. Paris: Presses Universitaires de France. Martínez-Sopena, Pascual. 1995a. Antroponimia y sociedad. Sistemas de identificación hispano-cristianos en los siglos IX y XIII [Anthroponymy and society. Hispano-Christian identification systems in the 9th and 13th centuries]. Santiago de Compostela: Universidade de Santiago de Compostela.

Martínez-Sopena, Pascual. 1995b. La antroponimia leonesa: Un estudio del archivo de la catedral de León (876-1200) [Anthroponymy in Leon: A study of the of the archives in the catedral in Leon (876-1200)]. In Antroponimia y sociedad. Sistemas de identificación hispano-cristianos en los siglos IX y XIII. Edited by Pascual Martínez-Sopena. Santiago de Compostela: Universidade de Santiago de Compostela, pp. 155-80.

Mazurczak, Filip. 2014. A Catholic revival in Northern Europe. The 2015 Synod: Bishops and the Future of Marriage. Available online: http://www.thecatholicthing.org/2014/11/29/a-catholic-revival-in-northerneurope/ (accessed on 8 February 2020).

Miles, Matthew B., and A. Michael Huberman. 1994. Qualitative Data Analysis: An Expanded Sourcebook. Thousand Oaks: SAGE.

Mille, Pierre. 1922. Préface [Preface]. In Le Manuel des Prénoms. Edited by Édouard Lévy. Paris: Rousseau \& Cie. Minnis, John, and Trevor Mitchell. 2007. Religion and Place in Leeds. Swindon: English Heritage, Cambridge University Press.

Monter, E. William. 1979. Historical demography and religious history in sixteenth-century Geneva. Journal of Interdisciplinary History 9: 399-427. [CrossRef]

Montes del Castillo, Ángel, and María José Martínez. 2011. Diversidad Cultural y Religión. Minorías Religiosas en la Región de Murcia. Madrid: Icaria Editorial.

Oppenheimer, Walter. 2005. Católicos y anglicanos salvan una de sus principales diferencias para la unidad [Catholics and Anglicans Settle One of Their Main Differences for the Sake of Unity]. El País. Available online: http://elpais.com/diario/2005/05/18/sociedad/1116367203_850215.html (accessed on 23 October 2019).

Oxford Dictionary. 2020. Middle East. Available online: http://www.oxforddictionaries.com/es/definicion/ingles/ middle-east (accessed on 12 April 2019). 
Payment, Richard. 2015. For Want of Wonders. Birmingham: Alan Wherry.

Perl, Paul, and Jonathon L. Wiggins. 2004. Don't Call Me Ishmael: Religious Naming among Protestants and Catholics in the United States. Journal for the Scientific Study of Religion 43: 209-28. [CrossRef]

Pommier, Gérard. 2013. Le nom propre. Fonctions logiques et inconscientes [The proper name: Logical and unconscious functions]. Paris: Presses Universitaires de France.

Postles, D., ed. 2002. Naming, Society and Regional Identity. Oxford: Leopard's Head Press.

Real Academia Española. 2011. Diccionario de la Lengua española [Dictionary of Spanish language]. Madrid: Espasa. First published 2001.

Redmonds, George. 2004. Christian Names in Local and Family History. Toronto: Dundurn.

Rincón, Delio. 1991. Recogida y Análisis de Datos Cualitativos [Collection and analysis of qualitative data]. Barcelona: Universitat de Barcelona.

Robson, John M. 1988. Surnames and social status in Victorian England. Queen's Quarterly 95: 642-61.

Rodríguez, Y., M. Fonseca, and R. C. Rivera. n.d. Diseño de la investigación. Unidad VIII [Computer Software: PowerPoint]. Puerto Rico: Universidad del Este.

Ryan, Emma. 2019. Why faith has always come second as Christianity in Leeds changes with the times? Has faith ever been a priority in Leeds? Yorkshire Evening Post. Available online: https://www.yorkshireeveningpost.co. uk/news/people/why-faith-has-always-come-second-christianity-leeds-changes-times-1332784 (accessed on 14 September 2020).

Salahuddin, Ahmed. 1999. A Dictionary of Muslim Names. London: Hurst \& Company.

Serrano, Francisca José. 2008. El Cuestionario en la Investigación en Ciencias Sociales [The questionnaire in the research in Social Sciences]. Paper presented at the Seminario de la Asociación Extremeña de Ciencias Matemáticas Ventura Reyes Prósper, Badajoz, Spain.

Social Issues Research Centre (SIRC). 2007. Belonging. Research Commissioned by the Automobile Association. Available online: http://www.sirc.org/publik/belonging.pdf (accessed on 18 September 2019).

Smith, Daniel S. 1985. Child-naming practices, kinship, ties, and change in family attitudes in Hingham, Massachusetts, 1641 to 1880. Journal of Social History 18: 541-66. [CrossRef]

SPSS, Inc., an IBM Company. 2010. IBM SPSS Statistics Version 19.0.0. Chicago: SPSS, Inc., an IBM Company. First published 1989.

Stoppe, Rhonda. 2018. Who Was Esther and Why Was She so Important? Crosswalk.com. Available online: https: //www.crosswalk.com/faith/bible-study/who-was-esther-and-why-was-she-so-important.html (accessed on 13 June 2020).

Taillefer de Haya, Lidia. 2007. Aportaciones de las mujeres a la lengua inglesa [Contributions of women to the English language]. In Mujeres, Simbolismo y vida: Estudios Sobre Mujeres. Edited by María Ángeles Durán and María Viedma. Malaga: Universidad de Malaga Servicio de Publicaciones, pp. 267-78.

Tibón, Gutierre. 2002. Diccionario etimológico comparado de nombres propios de persona [Comparative etymological dictionary of people's proper names]. Mexico City: Fondo de Cultura Económica, First publish 1956.

Trubetzkoy, Nicolai Sergeievich. 1973. Principios de Fonología [Principles of Phonology]. Translated by Delia García-Giordano. Madrid: Editorial Cincel. First published 1939.

Tsiropulos, Kostas E. 1987. El signo de puntuación. Sobre antroponimia [The punctuation mark. about anthroponymy]. Translated by Vicente Fernández-González. Barcelona: Kyklades.

Tusell, Javier. 1999. Historia de España en el siglo XX [History of Spain in the 20th Century]. Madrid: Taurus.

Udo-Solomon, Solomon. 2013. The Testimony of the Son of Man and the Beginning of His Millenial Reign on Earth. Pittsburgh: Dorrance Publishing, vol. 1.

Ullmann, Stephen. 1962. Semantics. An Introduction to the Science of Meaning. Oxford: Basil Blackwell.

Valentine, Tim, Tim Brennen, and Serge Brédart. 1996. The Cognitive Psychology of Proper Names. On the Importance of Being Ernest. London: Routledge.

Visauta, Bienvenido. 1989. Técnicas de Investigación Social I: Recogida de Datos [Techniques of Social Research I: Data Collection]. Barcelona: PPU.

Walter, Elizabeth. 2008. Cambridge Advanced Learner's Dictionary. Cambridge: Cambridge University Press.

Withycombe, Elizabeth Gidley. 1977. The Oxford Dictionary of English Christian Names. Oxford: Oxford University Press. First published 1945. 
Yonge, Charlotte Mary. 1863. History of Christian Names. London: Parker, Son and Bourn.

Publisher's Note: MDPI stays neutral with regard to jurisdictional claims in published maps and institutional affiliations.

(C) 2020 by the author. Licensee MDPI, Basel, Switzerland. This article is an open access article distributed under the terms and conditions of the Creative Commons Attribution (CC BY) license (http://creativecommons.org/licenses/by/4.0/). 